OPEN ACCESS

Edited by:

Natascha Riedinger, Oklahoma State University, United States

Reviewed by: Maxwell Lechte, McGill University, Canada Michelle Abshire, Valley City State University, United States

*Correspondence:

Peir K. Pufahl

peir.pufahl@queensu.ca

Specialty section: This article was submitted to

Biogeoscience,

a section of the journal

Frontiers in Earth Science

Received: 18 February 2021 Accepted: 03 August 2021 Published: 18 August 2021

Citation: Dunn SK, Pufahl PK, Murphy J B and Lokier SW (2021) Middle Ordovician Upwelling-Related Ironstone of North Wales: Coated Grains, Ocean Chemistry, and Biological Evolution.

Front. Earth Sci. 9:669476.

doi: 10.3389/feart.2021.669476

\section{Middle Ordovician Upwelling-Related Ironstone of North Wales: Coated Grains, Ocean Chemistry, and Biological Evolution}

\author{
Sarah K. Dunn ${ }^{1}$, Peir K. Pufahl' ${ }^{2,1 *}$, J. Brendan Murphy ${ }^{3}$ and Stephen W. Lokier ${ }^{4}$ \\ ${ }^{1}$ Department of Earth and Environmental Science, Acadia University, Wolfville, Nova Scotia, ${ }^{2}$ Department of Geological Sciences \\ and Geological Engineering, Queen's University, Kingston, ON, Canada, ${ }^{3}$ Department of Earth Sciences, St. Francis Xavier \\ University, Antigonish, Nova Scotia, ${ }^{4}$ School of Ocean Sciences, Bangor University, Bangor, United Kingdom
}

Middle Ordovician phosphatic ironstone of the Welsh Basin provides new insight into the paleoenvironmental significance of ironstone and Ordovician ocean chemistry. Deposition occurred in a back-arc basin along the southern margin of Avalonia as the Rheic Ocean opened to the south. Ironstone is interpreted to have accumulated as part of an aggradational parasequence on a storm-dominated shelf with coastal upwelling. This parasequence has a laminated pyritic mudstone base that grades upward into variably bioturbated mudstone and coated grain-rich, intraclastic ironstone, which is overlain in turn by cross-stratified grainstone composed entirely of coated Fe grains. A coarser clastic parasequence composed of more proximal lithofacies rests conformably above and suggests the contact between the two parasequences is a maximum flooding surface marking the onset of highstand conditions. Lithofacies associations suggest that sustained coastal upwelling created a wedge of nutrientrich, ferruginous seawater on the middle shelf that stimulated high surface ocean productivities. Large, coated Fe grains (granule size) composed of discontinuous and concentric carbonate fluorapatite, hematite, and chamosite cortical layers record fluctuations in pore water $E_{h}$ that are interpreted to have been related to changes in upwelling intensity and intermittent storm reworking of the seafloor. Results support an emerging model for Ordovician ironstone underpinned by the development of ferruginous bottom water that was periodically tapped by coastal upwelling. Expanding, semi-restricted seaways such as the Rheic Ocean were ideal locations for the ponding of this anoxic, hydrothermally enriched seawater, especially during the early Paleozoic when the deep ocean was variably and inconsistently oxygenated. The coincidence of ironstone depositional episodes with graptolite diversification events suggests that, in addition to $\mathrm{Fe}$, the sustained supply of upwelling-related $\mathrm{P}$ may have driven the radiation of some planktonic ecosystems during the Great Ordovician Biodiversification Event. Concomitant minor extinctions of benthic trilobites occurred as these ferruginous waters impinged on the shelf.

Keywords: ironstone, Wales, sedimentology, geochemistry, upwelling, ferruginous seawater, coated grains, biologic evolution 


\section{INTRODUCTION}

Ironstone is a Phanerozoic marine biochemical sedimentary rock type with an Fe content of greater than $15 \mathrm{wt} \%$ (Van Houten and Bhattacharyya, 1982; Van Houten and Arthur, 1989; Young et al., 1989; Pufahl, 2010). Most ironstone is aluminous, phosphaterich, and contemporaneous with major intervals of phosphorite accumulation (Young, 1992). Phosphorite, an important fertilizer ore, is also a marine biochemical sedimentary rock containing at least $18 \mathrm{wt} \% \mathrm{P}_{2} \mathrm{O}_{5}$ (Filippelli, 2008; Pufahl, 2010). The two most prominent episodes of coincident ironstone-phosphorite deposition occurred in the Ordovician and the Jurassic (Van Houten and Arthur, 1989; Young, 1992). Both periods generally correspond to intervals of increased tectonic activity, elevated hydrothermal input, globally warm climate, and biologic radiation in the marine realm (Figure 1; Van Houten and Bhattacharyya, 1982; Van Houten and Arthur, 1989; Sturesson et al., 2000; Servais et al., 2010).

The interplay of these processes ultimately controls the delivery, cycling, and sedimentation of $\mathrm{Fe}$ and $\mathrm{P}$ in the ocean
(Pufahl, 2010; Föllmi, 2016). Although the deposition of phosphatic sediment is generally well understood (e.g., Föllmi, 1996; Pufahl and Groat, 2017), processes governing ironstone accumulation remain poorly constrained. Phosphatic ironstone of the Welsh Basin (ca. $467 \mathrm{Ma}$ ) provides a unique opportunity to investigate these processes and their potential relationship to the Great Ordovician Biodiversification Event (GOBE; ca. 480-445 Ma), which is the largest sustained marine radiation in Earth history (Servais et al., 2009, 2010; Edwards, 2019). A distinguishing characteristic of this ironstone is the occurrence of large coated Fe grains. The size and variable mineralogy of coated grains provide an unparalleled window into water column and seafloor processes that facilitated ironstone precipitation.

The oceanography and depositional environments of phosphatic ironstone in the Welsh Basin are herein constrained by documenting their sedimentology and sequence stratigraphy. The diagenesis and paragenesis of lithofacies are interpreted in this framework to place these ironstones in their paleoenvironmental context, providing the basis for

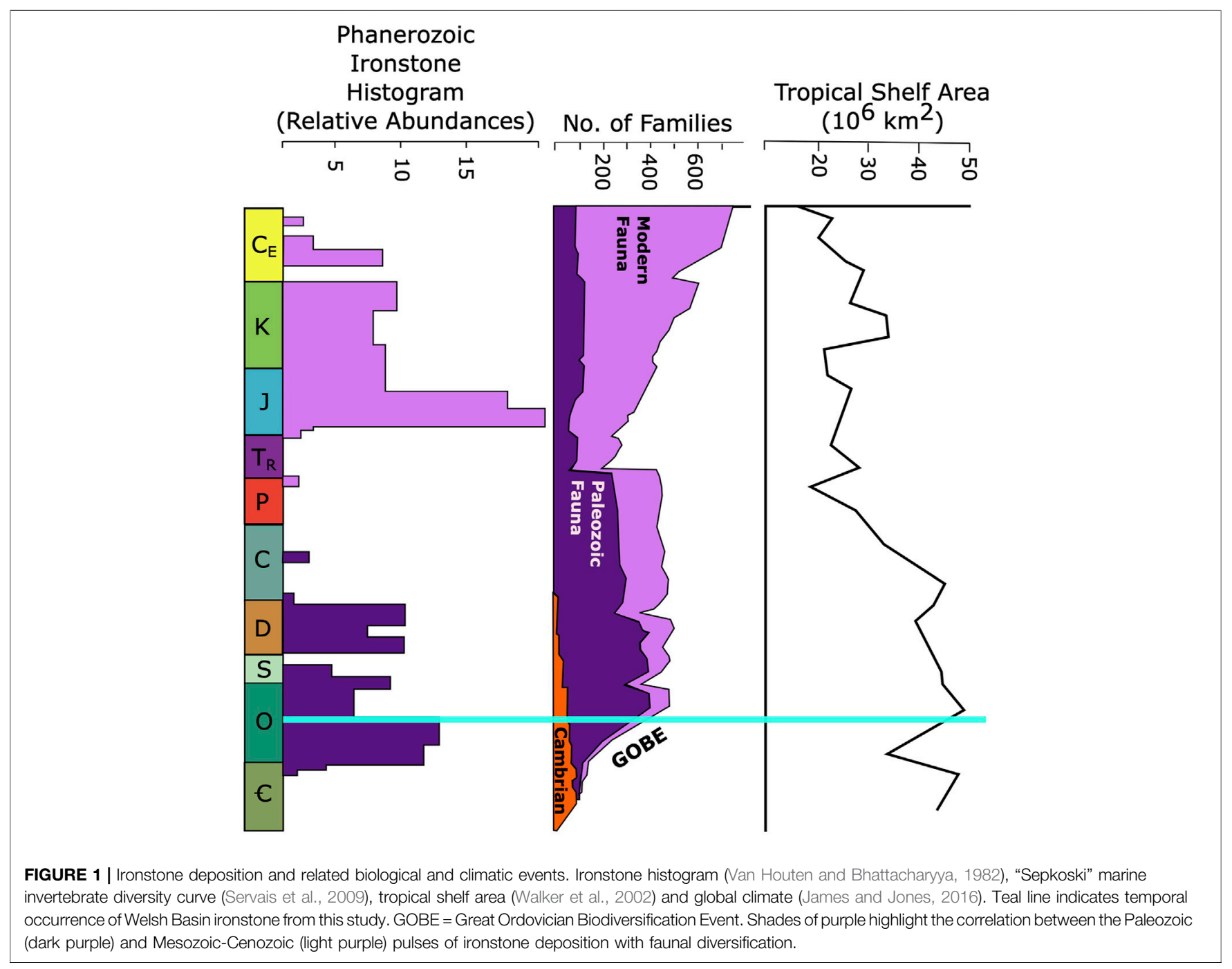



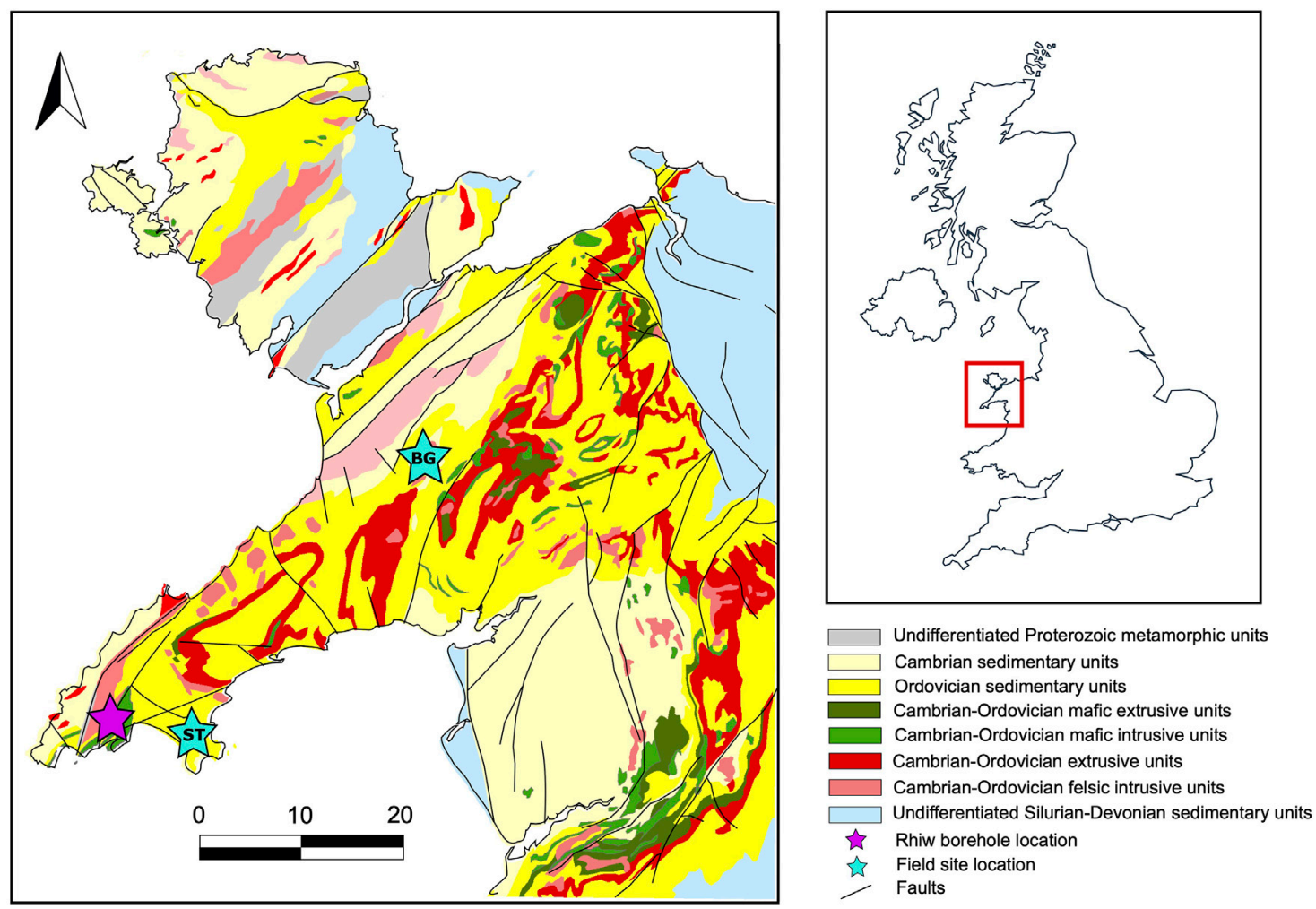

FIGURE 2 | Simplified geological map of North Wales, United Kingdom. BG = Betws Garmon; ST = St. Tudwal's Peninsula; R = Rhiw. From British Geological Survey materials ${ }^{\circledR}$ UKRI [2018].

understanding how changes in the benthic cycling of $\mathrm{Fe}$ and $\mathrm{P}$ produced coated Fe grains. Collectively, these data assist with understanding the relationship between changes in seawater chemistry, Ordovician tectonic events, and the GOBE.

\section{GENERAL GEOLOGY AND STRATIGRAPHY}

The Welsh Basin records major tectonic events in the early Paleozoic evolution of Avalonia (Figure 2). Sedimentation began in the Cambrian along a passive margin. By the Floian, the Welsh Basin had evolved into a back-arc basin with the onset of subduction along the southern flank of the Iapetus Ocean (Prigmore et al., 1997; Rushton and Howells. 1998; Brenchley et al., 2006; Howells, 2007; Murphy et al., 2008; van Staal et al., 2012). Such subduction caused rifting of Avalonia from Gondwana and the opening of the Rheic Ocean as a back-arc basin. As Avalonia drifted northward, the widening Rheic Ocean experienced increasing faunal endemism (Cocks and Torsvik, 2002; Fortey and Cocks, 2003; Linnemann et al., 2012; Pothier et al., 2015; Henderson et al., 2016). Arc-related volcanism in the Welsh Basin ceased when Baltica and Avalonia collided during the late Sandbian to earliest Katian (van Staal et al., 1998; Torsvik and Rehnström, 2003; Murphy et al., 2004; Henderson et al., 2016).

In the Welsh Basin, Ordovician strata consist of the ironstone-bearing Ogwen Group (Woodcock, 1990), which is bounded by major, basin-wide unconformities. Its basal unconformity records uplift associated with the onset of Iapetan subduction whereas the upper unconformity developed during collision with Baltica (Woodcock, 1990; Rushton and Fortey, 2000; Brenchley et al., 2006; Howells, 2007). The Ogwen Group ranges in thickness from 1 to $2 \mathrm{~km}$ and preserves a continuous record of early Floian to middle Katian (Arenig to Caradoc in the United Kingdom) marine sedimentation (Rushton and Howells, 1998; Rushton and Fortey, 2000; Brenchley et al., 2006; Howells, 2007). From base to top, the Ogwen Group consists of the Wig Bach Formation, Llanengan Mudstone Formation, Tygarn Formation, unsubdivided Nant Ffrancon Subgroup, Ty'r Gawen Mudstone Formation, Cwm Eigiau Formation, and Nod Glas Formation (Figure 3; Rushton and Fortey, 2000). Collectively, these units define a fining upward and deepening succession from fan delta and shoreface deposits to deep-water, pyrite-rich, graptolitic mudstone (Howells and Smith, 1997; Rushton and Fortey, 2000; Young et al., 2002). Paleocurrent directions from cross-bedded and rippled sandstones indicate a predominance of east-northeast directed shelf currents on a south-easterly dipping paleoslope (Beckly, 1988; Young et al., 2002; Howells, 2007).

Phosphatic granular ironstone occurs as discrete decimeter-thick horizons in the Wig Bach, Tygarn and Ty'r Gawen Mudstone formations. These horizons are penecontemporaneous with other ironstone beds in eastern 


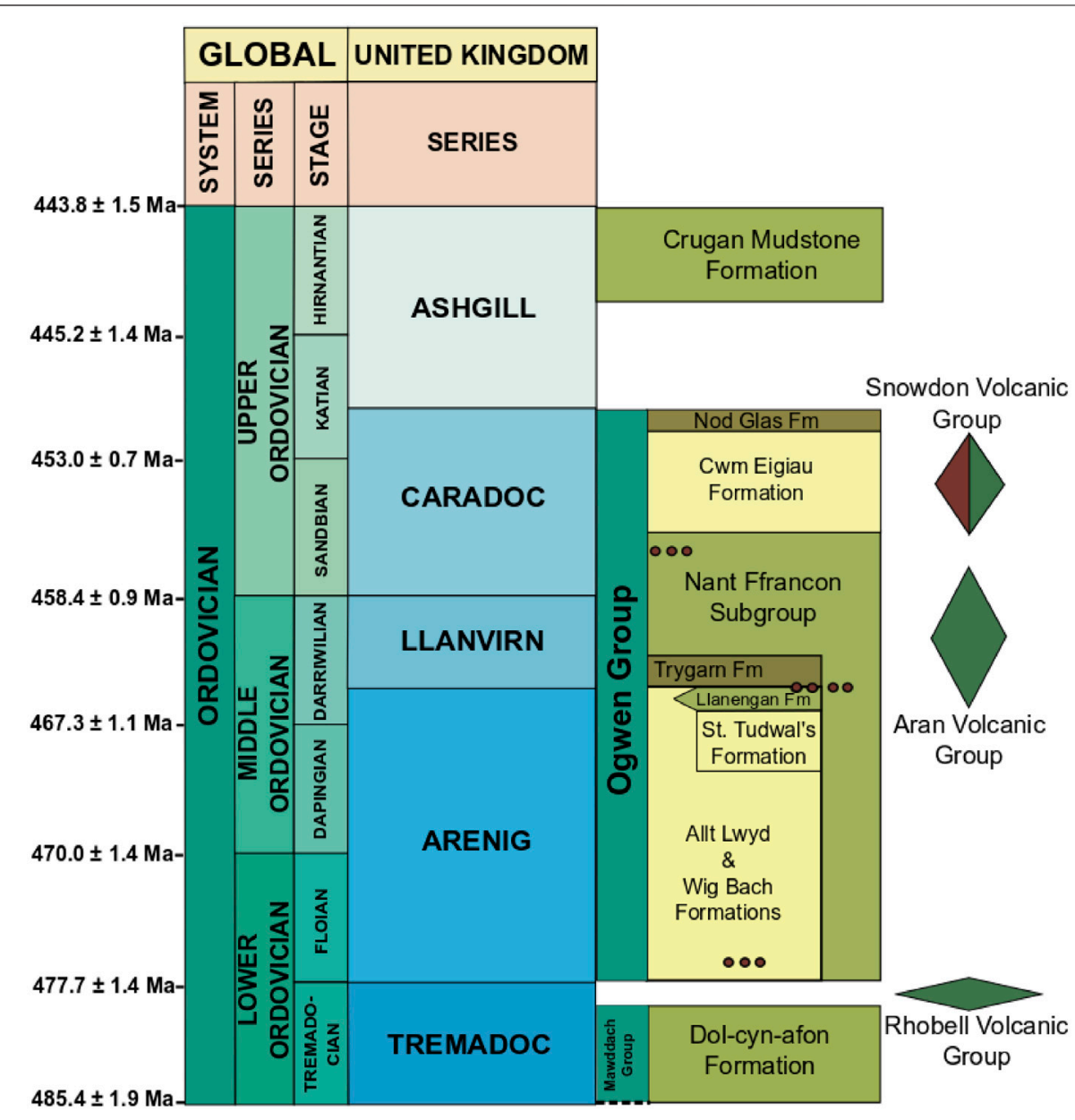

Shallow marine siliciclastic sedimentary rocks

Distal and deep marine chemical and siliciclastic sedimentary rocks

Pelagic sedimentary rocks

Igneous mafic rocks

Igneous felsic rocks

๑ ० Ironstone horizon

FIGURE 3 | General stratigraphy of Ordovician sedimentary rocks, North Wales (modified from Rushton and Fortey, 2000). Only the ironstone of the Arenig/Llanvirn boundary was investigated in this study. Global (Cohen et al., 2019) and local series names (Cooper et al., 2012) are shown for comparison.

North America, southwestern Europe and North Africa (Young, 1989; Young et al., 1989; Woodcock, 1990; Young, 1992; Young et al., 2002; Todd et al., 2019), which also accumulated along the margins of the Rheic Ocean. Research herein focuses on the Darrwilian Hen-dy-Capel Ironstone Member of the Tygarn Formation (Figure 3; Trythall et al., 1987; Young et al., 2002) because it provides the clearest window into ironstone depositional processes. Unlike other ironstone horizons in Wales, the Hen-dy-Capel Ironstone Member is well-exposed in old mining adits and quarries.

\section{METHODS}

Three field sites and two drill cores were examined to investigate the lateral and vertical facies variation of the Hen-dy-Capel Ironstone Member (Figure 2). At Betws Garmon eight adits, mined during the 19th century and through World War 1 for steel production (Strahan et al., 1920), allowed lateral correlation of lithofacies along $1 \mathrm{~km}$ of depositional strike. Two field sites on St. Tudwal's Peninsula in small, abandoned open pit mines yielded information on the regional variability of ironstone and associated 
facies. Drill cores from near the town of Rhiw (Brown and Evans, 1989) provided further insight into the stacking relationships of lithofacies. Stratigraphic sections were described on a bed-by-bed basis to develop a lithofacies nomenclature, define important sequence stratigraphic surfaces, and interpret paleoenvironments of deposition through time. The Folk classification (Folk, 1980) was used to define terrigenous clastic facies, whereas a modified Dunham classification scheme (Dunham, 1962) was employed to characterize ironstone because these chemical sedimentary rocks share similar textural attributes to limestone (Young, 1989; Pufahl, 2010). Bioturbation was categorized using the Droser and Bottjer (1986) ichnofabric index from 1 (no activity) to 6 (complete homogenization by bioturbation).

Seventy-four polished thin sections were examined using a Nikon Optiphot-POL transmitted and reflected light microscope. Modal compositions of minerals and fossils were estimated using a visual percentage chart (Terry and Chilingar, 1955) with an abundance index of rare (<10\%), uncommon (11-40\%), common (41-70\%), and abundant ( $>70 \%)$. Minerals were identified in thin section by their petrographic characteristics and through profilefitting of X-ray powder diffractograms. Plagioclase compositions were determined under transmitted light using the Michel-Lévy method (Sørensen, 2013).

Twelve whole rock powders were analyzed on a MalvernPanalytical Empyrean Series 2 X-ray diffractometer with a programmable PIXcel3D area detector across scattering angles from $4^{\circ}$ to $80^{\circ}$ using a copper X-ray target source. Although a $\mathrm{Cu}$ source causes fluorescence of Fe-rich minerals, programming the peak height discrimination setting on the detector to $54 \%$ improved peak-to-background ratios on diffractograms for mineral identification in ironstone lithofacies. Mineralogy was interpreted from X-ray powder diffractograms using MalvernPanalytical's HighScore Plus software package.

Important paragenetic relationships were further analyzed using a JEOL JSM6400 scanning electron microscope (SEM) equipped with a Genesis Energy Dispersive X-ray Analyzer at the Microscopy and Microanalysis Facility at the University of New Brunswick-Fredericton. Backscattered electron images and energy dispersive X-ray spectra were generated using an accelerating voltage of $15 \mathrm{kV}$ and a working distance of $27 \mathrm{~mm}$. Carbonate-rich samples were also investigated using a Nikon Eclipse E400-POL microscope equipped with a Reliotron III cathodoluminescence system to understand paragenetic relationships not visible under transmitted and reflected light microscopy and SEM imaging.

Whole rock geochemical analysis of 60 samples provides major, minor, and trace element data to further constrain ironstone depositional processes. Analyses were performed at AGAT Laboratories, Mississauga, using a combination of $\mathrm{Li}$ borate fusion with an X-ray fluorescence finish and $\mathrm{Na}$ peroxide fusion with an inductively coupled plasma optical emission spectrometry (ICP-OES)/inductively coupled plasma mass spectrometry (ICPMS) finish. Total organic C (TOC) was analyzed using LECO combustion infrared spectroscopy. Replicate analyses indicate a reproducibility for major elemental concentrations using Li borate fusion and an XRF finish of $\pm 2 \%$. REE $+\mathrm{Y}$ and other trace element concentrations determined using a Na peroxide fusion and an ICPOES/ICP-MS finish have a reproducibility of $\pm 10 \%$. The reproducibility of TOC concentrations using LECO combustion is $\pm 1 \%$. Organic-matter-rich lithofacies contain $>0.5 \mathrm{wt} \%$ TOC (Trabucho-Alexandre, 2015). The geostandards SY-4 (diorite gneiss), 692 (iron ore), GBM998-10 (multi-metal nickel ore), and Till-2 (till) were used as matrix matching standards for various facies. Whole-rock geochemical data were plotted using GCDkit 5.0 in R 3.4.3 (Janoušek et al., 2016).

Rare earth elements and yttrium $(\mathrm{REE}+\mathrm{Y})$ concentrations are normalized with respect to the Post Archean Australian Shale standard (PAAS; McLennan, 1989) to understand redox controlled processes of $\mathrm{Fe}$ and $\mathrm{P}$ precipitation. $\mathrm{Ce}$ and $\mathrm{Eu}$ anomalies are calculated as shale normalized (subscript $\mathrm{SN}$ ) $\mathrm{Ce}_{\mathrm{SN}} / \mathrm{Ce}_{\mathrm{SN}} *$ and $\mathrm{Eu}_{\mathrm{SN}} / \mathrm{Eu}_{\mathrm{SN}} *$, respectively (Bau et al., 2014), where:

$$
\begin{aligned}
& \mathrm{Ce}_{\mathrm{SN}} *=0.5 \mathrm{La}_{\mathrm{SN}}+0.5 \operatorname{Pr}_{\mathrm{SN}} \\
& \mathrm{Eu}_{\mathrm{SN}} *=0.5 \mathrm{Sm}_{\mathrm{SN}}+0.5 \mathrm{Gd}_{\mathrm{SN}}
\end{aligned}
$$

Geochemical data are interpreted in paragenetic and sequence stratigraphic context to elucidate the source of Fe to the Welsh Basin and to create an oceanographic model for ironstone accumulation.

\section{LITHOFACIES AND PALEOENVIRONMENT}

Three terrigenous and four ironstone lithofacies are recognized in the Ogwen Group. Facies 1, 2, and 3 are siliciclastic and Facies 4, 5,6 , and 7 are authigenic and related to ironstone deposition. Lithofacies associations suggest deposition on an unrestricted, storm-dominated shelf.

\section{Facies 1-Wavy Laminated Sandy Siltstone}

Facies (F1) is composed of intercalated light and dark grey, wavy laminae that are 1-4 mm thick (Figures 4A,B). Light grey laminae are normally graded and composed of subrounded, very fine-grained and silt-sized quartz grains with rare detrital muscovite in a clay matrix. Dark grey laminae contain organic matter with disseminated silt-sized quartz grains and are locally bioturbated with an ichnofabric index of 2 .

Light grey, sandy laminae are interpreted as distal tempestites that formed near storm wave base because storm-induced combined flow was too weak to produce hummocky crossstratification (Plint, 2010; Smit et al., 2012). Dark grey laminae reflect suspension rain of sedimentary organic matter and siltsized quartz grains during fairweather conditions (Parrish, 1982; Ghadeer and Macquaker, 2011). The bioturbated nature of some laminae indicates the seafloor was at times sufficiently oxygenated to permit infaunal colonization between storms (Droser and Bottjer, 1986; Schieber, 2003).

\section{Facies 2-Parallel Laminated Micaceous Shale}

Facies 2 (F2) is a densely cleaved, thinly laminated, organic matterbearing shale (Figures 4C,D) with silt-sized detrital muscovite and quartz grains. The strong cleavage precludes the identification of burrows and other sedimentary structures that exist in some mudstone (Schieber, 2003; Ghadeer and Macquaker, 2011). 

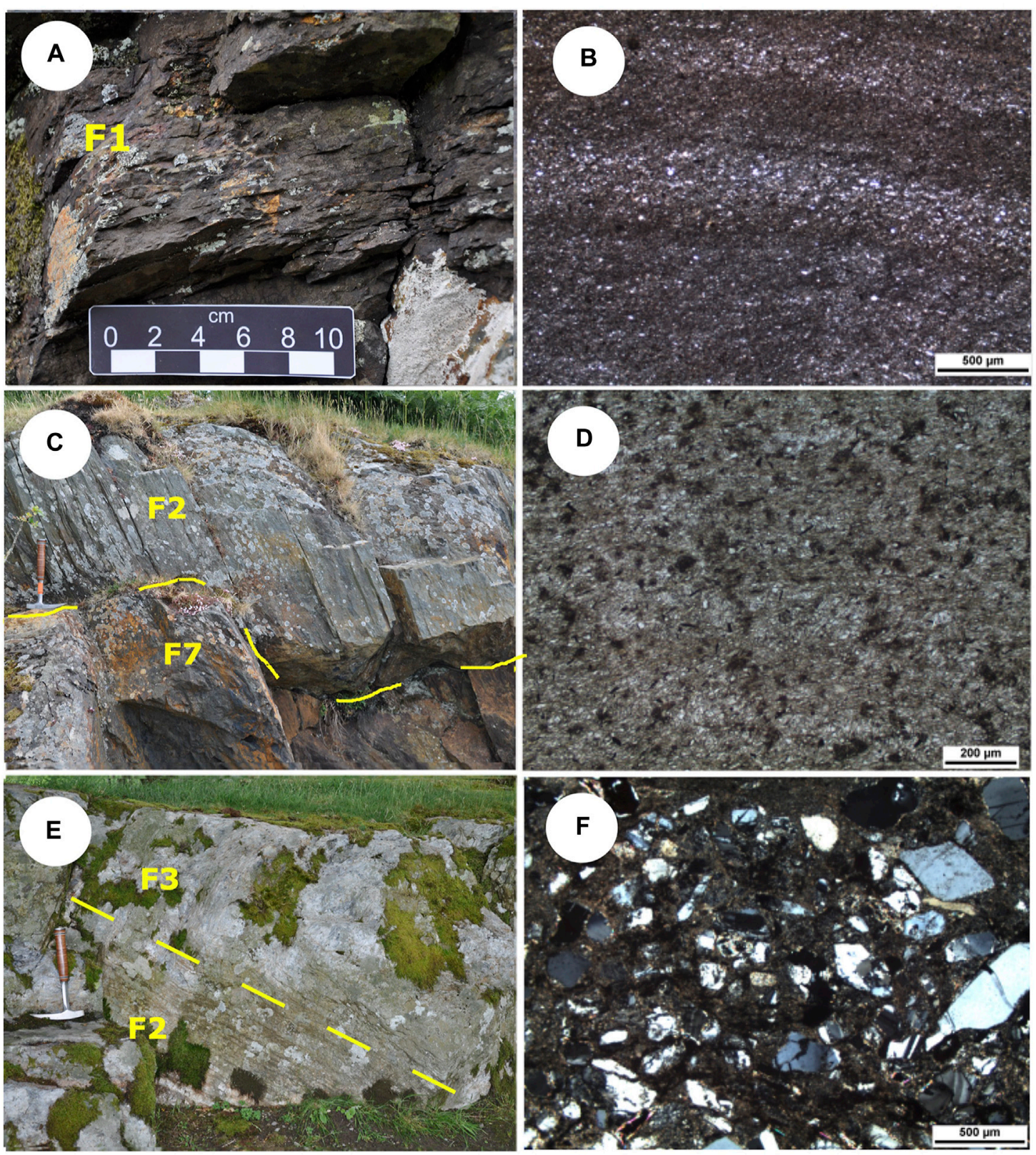

FIGURE 4 | (A) F1 wavy laminated sandy siltstone outcrop at Betws Garmon. (B) Photomicrograph of F1 silt and very fine grained sand laminae of quartz and Fesilicate (PPL). Sample HC-18-15 (C) F2 sharply overlying Fe-grainstone (F7) at Betws Garmon. Note near-vertical cleavage of the F2 slate. Hammer for scale is $30 \mathrm{~cm}$ in length; (D) F2 photomicrograph of low grade metamorphically altered shale (phyllite; PPL). Sample BG-18-01 (E) F3 outcrop separated by yellow line above laminated F2. Hammer for scale $30 \mathrm{~cm}$ (F) Photomicrograph of F3 Lithic and feldspar-rich grains. Note undulose and uniform extinction in quartz grains (XPL). Sample BG$18-17$.

The microbial respiration of organic matter accumulating beneath a productive surface ocean is interpreted to have increased the biological oxygen demand at the sediment-water interface and limited the establishment of an infaunal community (Parrish, 1982; Droser and Bottjer, 1986; Dunbar and Barrett, 2005). Although not observed because of the cleavage, cryptoburrows, organo-mineralic aggregates, subtle erosion features, and flocripples that likely formed as mud accumulated near storm wave base through a combination of suspension settling, density flow, and traction currents (Schieber, 2003; Ghadeer and Macquaker, 2011).

\section{Facies 3-Hummocky Cross-Stratified Sublitharenite}

Facies 3 (F3) is a light grey, hummocky cross-stratified (HCS) sublitharenite (Figures 4E,F). Bedsets are sometimes difficult 

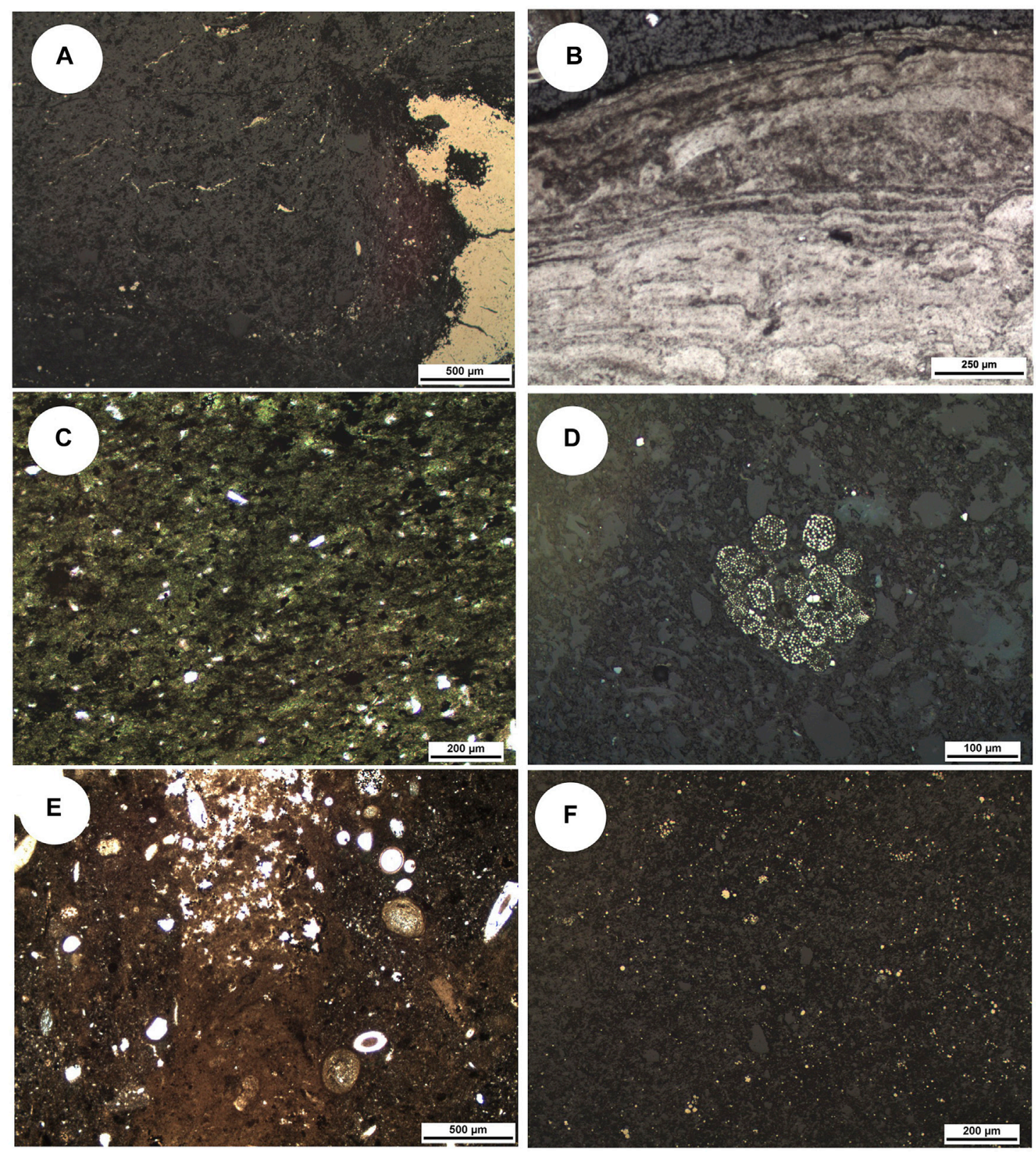

FIGURE 5 | (A) Reflected light (RL) photomicrograph of F4 laminated pyritic mudstone displaying rare pyrite nodule to right of frame. Sample HC-18-08 (B) Bacteriogenic precipitate of CFA (photomicrograph in PPL). Sample HC-18-09 (C) Photomicrograph of F5 massive chamosite mudstone with very fine quartz silt and organics (PPL). Sample BG-18-34B (D) Framboidal pyrite preserved in F5, only occurs as local clusters 100-200 $\mu$ m diameter (RL photomicrograph). Sample HC-1804 (E) Transmitted light photomicrograph of burrow preserved in a phosphate intraclast with passive infilling by terrigenous grains in F6. (F) Reflected light photomicrograph showing abundant disseminated framboidal pyrite (bright specs) in organic rich F6. Sample HC-18-16.

to discern because of intense localized bioturbation (ichnofabric index 6). Silt and fine sand-sized quartz, plagioclase $\left(\mathrm{An}_{35}\right.$ - andesine), K-feldspar, and lithic clasts are subrounded and moderately well-sorted in a detrital clay matrix.

This facies is interpreted to have accumulated between fairweather and storm wave-bases through combined flow (Dott and
Bourgeois, 1982; Dumas and Arnott, 2006; Boyd, 2010; Quin, 2011; Mulhern et al., 2019). The intense bioturbation reflects accumulation on a well oxygenated seafloor. The immaturity of grains and occurrence of andesine probably records the delivery of clastic material derived from a proximal igneous source of intermediate to felsic composition (Anthony et al., 2001; Nesse, 2015). 


\section{Facies 4-Laminated Black Pyritic Mudstone}

Facies 4 (F4) is a blue-black, organic matter-rich mudstone with an ichnofabric index of 1 (Figures 5A,B). Laminae are $1-3 \mathrm{~mm}$ thick and, in addition to abundant organic matter, contain common framboidal pyrite $\left(\mathrm{Fe}^{2+} \mathrm{S}_{2}\right)$ and rare coated $\mathrm{Fe}$ grains. The most organic matter-rich laminae may also contain granulesized, in situ carbonate fluorapatite (CFA; Ca10-abNaaMgb(PO4)6-x(CO3)x-y-z(CO3·F)x-y-z(SO4)zF2) peloids.

The abundance of organic matter in this facies implies deposition beneath a highly productive surface ocean (Froelich et al., 1979; Challands et al., 2009; Piper and Calvert, 2009; Pufahl and Groat, 2017). The thinly laminated character of the facies suggests deposition below storm wave base. The lack of bioturbation and presence of framboidal pyrite are interpreted to record anoxic bottom and pore waters (Glenn and Arthur, 1988; Taylor and Macquaker, 2000; Schieber, 2003. The cooccurrence of framboidal pyrite and in situ authigenic CFA peloids indicate that as sedimentary organic matter was respired by a consortium of microbes, bacterial sulfate reduction not only produced $\mathrm{H}_{2} \mathrm{~S}$ for pyrite precipitation, but also released phosphate to pore water for phosphogenesis (Schieber, 2002; Arning et al., 2009; Taylor and Konhauser, 2011; Hiatt et al., 2015).

\section{Facies 5-Bioturbated Chamositic Mudstone}

Facies 5 (F5) is a dark blue-black chamositic mudstone (Figures 5C,D). Bioturbation has destroyed bedding (ichnofabric index of $4-5)$ to create diffuse layers containing varying proportions of silt-sized quartz grains and rare, granule-to pebble-sized coated Fe grains. Coated grain mineralogy is dependent on whether cortical layers completely or partially envelop the nucleus. Continuous cortical layers are composed primarily of chamosite $\left(\mathrm{Fe}_{3}^{2+} \mathrm{Mg}_{1.5} \mathrm{AlFe}_{0.5}^{3+} \mathrm{Si}_{3} \mathrm{AlO}_{12}(\mathrm{OH})_{6}\right)$ intercalated with CFA and chert $\left(\mathrm{SiO}_{2}\right)$. Discontinuous cortical layers are typically dominated by goethite $\left(\mathrm{Fe}^{3+} \mathrm{O}(\mathrm{OH})\right)$ or hematite $\left(\mathrm{Fe}_{2}^{3+} \mathrm{O}_{3}\right)$. More organic-rich areas of this facies also contain rare framboidal pyrite and rare pebble-sized CFA nodules (1-3 cm in diameter).

Pervasive bioturbation and the occurrence of chamosite are characteristic of a well oxygenated seafloor and suboxic sediment pile where precipitation near the Fe-redox boundary produced coated grains (Droser and Bottjer, 1986; Glenn and Arthur, 1988; Pufahl and Grimm, 2003). Suboxic in this sense refers to a relative measure of oxygen levels in the sediment and does not refer to specific oxygen concentrations (cf. Canfield and Thamdrup, 2009).

Chamosite characteristically contains both $\mathrm{Fe}^{2+}$ and $\mathrm{Fe}^{3+}$ and thus, is interpreted to have precipitated during suboxic authigenesis in conditions that straddled the Fe-redox boundary (Harder, 1980; Glenn and Arthur, 1988; Pufahl and Grimm, 2003). Fe-redox pumping probably sustained precipitation by maintaining high levels of $\mathrm{Fe}$ beneath the seafloor. Fe-redox pumping is a cyclic mechanism that concentrates mobile $\mathrm{Fe}^{2+}$ in pore water through the dissolution of $\mathrm{Fe}$-(oxyhydr)oxide buried below the Fe redox interface
(Heggie et al., 1990). Dissolution and liberation of $\mathrm{Fe}^{2+}$ is aided by the microbial reduction of Fe (Konhauser et al., 2011). The escape of $\mathrm{Fe}$ out of the sediment is prevented by reprecipitation of $\mathrm{Fe}$ (oxyhydr)oxide above this boundary.

As in coated phosphate grains, intercalated CFA and chert cortical layers in coated chamosite grains are interpreted to record minor fluctuations in the vertical position of the $\mathrm{Fe}$ redox boundary in sediment and changes in the concentrations of pore water phosphate and silica. Phosphate was probably released to pore water through a combination of $\mathrm{Fe}$ redox pumping, which also concentrates pore water $\mathrm{P}$, and microbial degradation of sedimentary organic matter (Heggie et al., 1990; Jarvis et al., 1994; Arning et al., 2009; Hiatt et al., 2015; Pufahl and Groat, 2017). Silicon required for chamosite precipitation was probably derived from silica remobilized through the dissolution of sponge spicules in the sediment.

Coated grains composed of discontinuous hematite and goethite cortical layers preserve micro-unconformities and indicate that F5 is a condensed facies (Todd et al., 2019). These internal cortical erosion surfaces record multiple episodes of precipitation, exhumation, and erosion, followed by reburial and further precipitation near the Fe redox boundary (Pufahl and Grimm, 2003). Such stratigraphic condensation is interpreted to have stabilized this zone of precipitation beneath the seafloor long enough to create pebble-sized coated grains (Pufahl and Grimm, 2003; Raiswell and Canfield, 2012; Föllmi, 2016).

The growth of pebble-sized CFA nodules also reflects the importance of low sedimentation rates on maintaining high pore water phosphate levels (Jarvis et al., 1994; Föllmi, 2016; Pufahl and Groat, 2017). As in F4, the co-occurrence of framboidal pyrite indicates bacterial sulfate reduction was an important source of this phosphate.

\section{Facies 6: Structureless Coated Fe Grain Packstone}

Facies 6 (F6) is generally a blue-black, structureless, chamositic packstone composed of coarse-grained to granule-sized coated $\mathrm{Fe}$ grains, mudstone intraclasts, and pebble-sized CFA nodules (Figures 5E,F). Locally, HCS and scouring occur where the grainsize is finer. Matrix material is a chamosite-rich siltstone containing sponge spicules and framboidal pyrite. Although bioturbation appears negligible (ichnofabric index of 2), the grain size and dark colour make it difficult to assess.

Large coated Fe grains (ca. $15 \mathrm{~mm}$ in diameter) are the most conspicuous characteristic of this facies (Figures 6A,B). Grain cortices are formed of concentric and discontinuous layers of CFA, hematite, and chamosite. Cortical layers nucleated on chamositic mudstone clasts, sponge spicules, and benthic foraminifera.

The authigenic processes that produced coated grains, CFA nodules, and framboidal pyrite are similar to those that produced coated grains in F5. The occurrence of coated grains and intraclasts reinforce the interpretation that F6 is also a condensed facies (Pufahl and Grimm, 2003; Föllmi, 2016; Todd et al., 2019), but the HCS and scouring suggests 

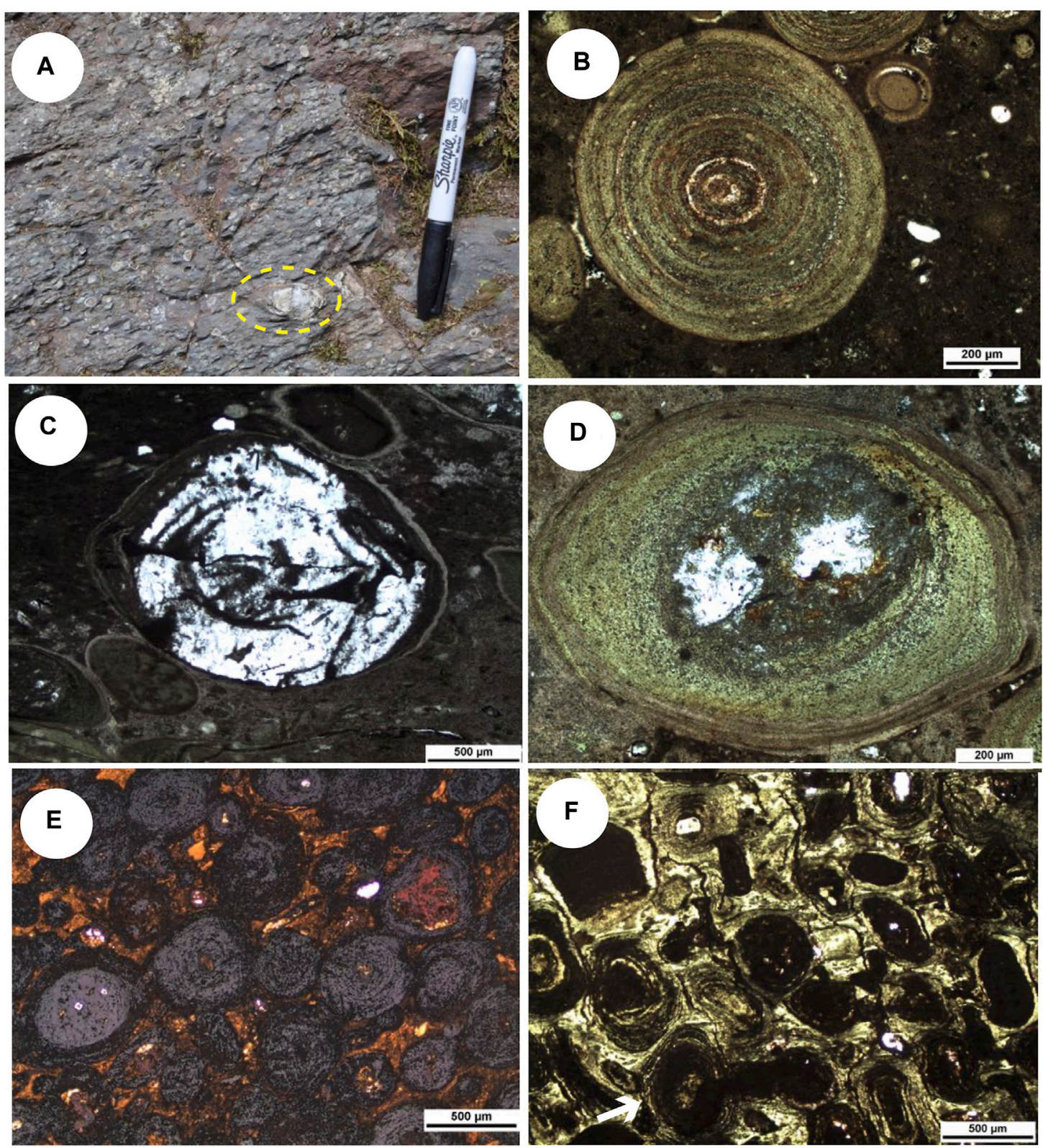

FIGURE 6 | (A) F6 Field photograph displaying the coarsest coated grains (ca. $15 \mathrm{~mm}$ ) observed in the Welsh ironstone, Betws Garmon. Yellow dashed ellipse highlights pebble-sized phosphtaic nodule. $15 \mathrm{~cm}$ marker for scale. (B) F6 Thin section photomicrograph of a, Fe-silicate rich coated grain preserved within a CFA nodule. Mineralogical variation of laminae is apparent. Sample HC-18-07. (C,D) F6 transmitted light photomicrographs of silicified benthic foraminifera subsequently coated in CFA and chamosite laminae. (E) F7 transmitted and reflected light photomicrograph of magnetitic grainstone with cement oxidizing to goethite (orange). Sample BG -18-06. (F) F7 transmitted light photomicrograph of magnetitic grainstone with chamosite cement (light green). Spastolithic deformation with later compaction fractures from burial pressure after cementation. White arrow indicates spalled cortical layers in coated grain. Sample BG-18-26.

reworking by waves above storm wave base (Dott and Bourgeois, 1982; Dumas and Arnott, 2006; Quin, 2011). The abundance of sponge spicules implies a productive and well-oxygenated middle shelf capable of supporting filter feeders (Botting and Muir, 2013; Kidder and Tomescu, 2016). The nucleation of CFA on spicules indicates authigenic precipitation was rapid, occurring before the spicules dissolved and silica was remobilized through pore water (Behl and Garrison, 1994).

\section{Facies 7-Trough Cross-Stratified Coated Fe Grain Grainstone}

Facies 7 (F7) is a blue-black trough cross-stratified grainstone. Trough cross-stratified beds are ca. $10-50 \mathrm{~cm}$ thick and composed of well-sorted, fine-grained coated $\mathrm{Fe}$ grains (Figures 6C-F). Intraclast lags of reworked and broken CFA nodules occur at the base of some beds. In some beds, intense bioturbation (ichnofabric index of 6) has destroyed foresets and 


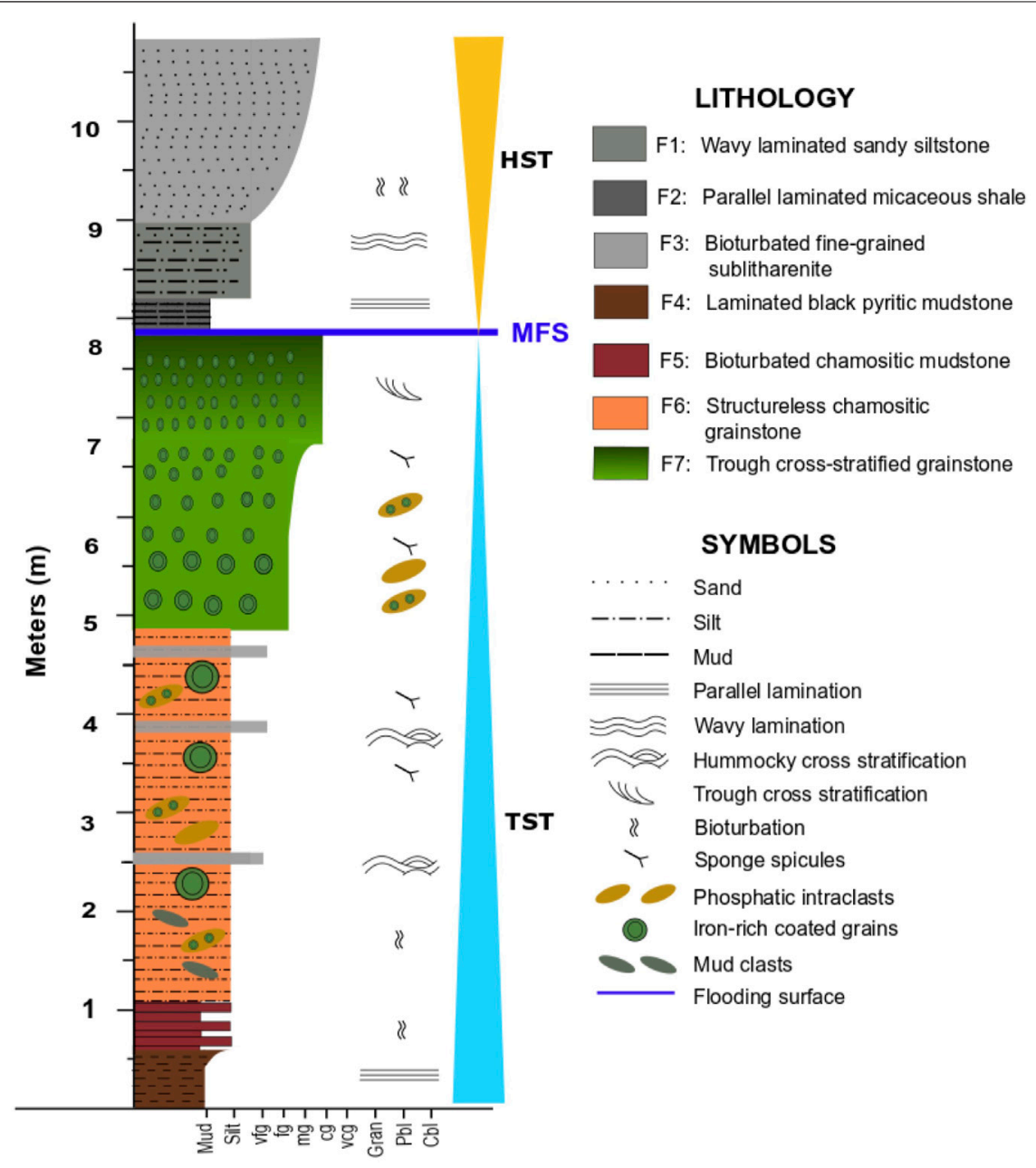

FIGURE 7 | Composite stratigraphic column showing stacking patterns of Welsh Basin ironstone. A shallowing-upward parasequence of abundant chemical sediments is sharply overlain by coarsening upward siliciclastic facies representing fundamentally different depositional regimes, of the transgressive and highstand system tracks (TST and HST), respectively. Grains size mud = mud, silt = silt, vfg = very fine grained, fg = fine-grained, $\mathrm{mg}=$ medium grained, $\mathrm{vcg}=$ very coarse grained, gran $=$ granule, $\mathrm{pbl}=$ pebble, $\mathrm{cbl}=$ cobble.

homogenized bedding contacts. Pore spaces are filled with chamosite and goethite (Figure 6E). Coated grains have a detrital quartz nucleus with discontinuous cortical layers composed primarily of chamosite and rare hematite. Where metamorphosed, grain cortices are altered to magnetite $\left(\mathrm{Fe}^{2+} \mathrm{Fe}_{2}^{3+} \mathrm{O}_{4}\right)$. Spastolithic deformation indicates grains were soft during early burial, and fracturing occurred after cementation during compaction from burial pressure (Figure 6F).

Small-scale trough cross-stratification generally reflects traction current deposition near fair weather wave base (Shanmugam et al., 1993; Dumas and Arnott, 2006; Plint, 2010). Fair weather waves and unidirectional currents are interpreted to have exhumed coated grains actively precipitating beneath the seafloor, reworking them into subaqueous dunes. Frequent reworking of the seafloor and exhumation of sediment in this proximal environment produced smaller coated grains with numerous cortical erosion surfaces (Todd et al., 2019). Chamosite cementing grains is interpreted to have precipitated where coated grains were buried deep enough to stop their exhumation. Although such reworking was a prerequisite for the genesis of coated grains in this facies, it prevented the authigenic cementation of grains until they were immobilized through burial (Pufahl and Grimm, 2003). Goethite between grains is probably a by-product of the oxidative chemical weathering of chamosite (Masuda et al., 2012; Galmed et al., 2021).

\section{SEQUENCE STRATIGRAPHY}

A parasequence is a relatively conformable succession of genetically related beds bounded at the bottom and top by flooding surfaces (Van Wagoner et al., 1988). Parasequences are the primary components of systems tracts, which define a stratigraphic sequence recording deposition through a complete 
TABLE 1 | Major element and total organic carbon (TOC) concentrations in lithofacies of the Hen-dy-Capel Ironstone Member, Tygarn Formation.

\begin{tabular}{|c|c|c|c|c|c|c|c|c|}
\hline \multirow[t]{2}{*}{ Sample } & \multirow[t]{2}{*}{ Facies } & \multirow{2}{*}{$\frac{\mathrm{Al} 2 \mathrm{O} 3}{\mathrm{wt} \%}$} & \multirow{2}{*}{$\frac{\text { Fe2O3 }}{\text { wt } \%}$} & \multirow{2}{*}{$\frac{\mathrm{K} 20}{w t \%}$} & \multirow{2}{*}{$\frac{\mathrm{P} 205}{w t \%}$} & \multirow{2}{*}{$\frac{\mathrm{SiO2}}{\mathrm{wt} \%}$} & \multirow{2}{*}{$\frac{\text { TiO2 }}{w t \%}$} & \multirow{2}{*}{$\frac{\text { TOC }}{\text { wt } \%}$} \\
\hline & & & & & & & & \\
\hline BG-18-04 & 1 & 15.30 & 27.40 & 0.86 & 0.50 & 44.80 & 0.80 & 0.49 \\
\hline $\mathrm{HC}-18-15$ & 1 & 17.60 & 31.40 & 0.36 & 0.43 & 38.20 & 0.85 & 0.27 \\
\hline BG-18-20 & 2 & 12.50 & 27.00 & 0.08 & 1.10 & 48.80 & 0.64 & 0.39 \\
\hline BG-18-27 & 2 & 13.40 & 32.40 & - & 0.53 & 44.00 & 0.67 & 0.38 \\
\hline $\mathrm{HC}-18-19$ & 2 & 21.00 & 13.70 & 3.65 & 0.23 & 50.80 & 0.97 & 0.25 \\
\hline BG-18-30 & 4 & 13.60 & 14.20 & 2.18 & 0.41 & 60.90 & 0.67 & 0.32 \\
\hline HC-18-18 & 4 & 20.00 & 20.30 & 2.49 & 0.16 & 44.80 & 1.02 & 0.97 \\
\hline BG-18-43 & 4 & 6.39 & 55.60 & 0.01 & 1.67 & 13.80 & 0.24 & 4.63 \\
\hline BG-18-13 & 5 & 3.84 & 69.40 & 0.01 & 3.38 & 6.37 & 0.13 & 0.23 \\
\hline BG-18-24 & 5 & 13.20 & 39.20 & - & 0.42 & 37.80 & 0.70 & 0.55 \\
\hline BG-18-25 & 5 & 12.40 & 36.20 & - & 0.90 & 41.30 & 0.62 & 0.37 \\
\hline BG-18-29 & 5 & 12.30 & 32.30 & - & 0.57 & 43.40 & 0.56 & 0.34 \\
\hline BG-18-38 & 5 & 13.00 & 31.00 & 0.01 & 1.56 & 43.20 & 0.67 & 0.31 \\
\hline BG-18-39 & 5 & 14.20 & 35.10 & - & 0.50 & 39.90 & 0.76 & 0.30 \\
\hline BG-18-40 & 5 & 10.70 & 35.70 & - & 1.62 & 40.10 & 0.58 & 0.36 \\
\hline BG-18-45 & 5 & 13.50 & 37.40 & - & 1.14 & 35.30 & 0.71 & 0.60 \\
\hline HC-18-08 & 5 & 15.90 & 35.50 & 0.01 & 0.13 & 38.50 & 0.86 & 0.55 \\
\hline PYG-18-07 & 5 & 14.80 & 31.50 & 0.34 & 0.39 & 42.50 & 0.86 & 0.54 \\
\hline BG-18-01-A & 6 & 6.53 & 53.90 & 0.06 & 1.96 & 24.30 & 0.29 & 1.07 \\
\hline BG-18-14 & 6 & 12.10 & 31.00 & 0.05 & 1.93 & 39.90 & 0.70 & 0.66 \\
\hline BG-18-15 & 6 & 8.08 & 45.00 & 0.03 & 2.14 & 30.20 & 0.36 & 0.37 \\
\hline BG-18-23 & 6 & 9.09 & 34.00 & 0.01 & 4.99 & 33.40 & 0.42 & 0.41 \\
\hline BG-18-28 & 6 & 9.47 & 44.30 & 0.03 & 0.64 & 31.20 & 0.46 & 0.59 \\
\hline BG-18-31 & 6 & 14.60 & 35.00 & 0.01 & 3.14 & 33.20 & 0.64 & 0.44 \\
\hline BG-18-34b & 6 & 12.20 & 40.50 & 0.02 & 0.52 & 37.20 & 0.68 & 0.27 \\
\hline BG-18-37 & 6 & 5.51 & 49.00 & 0.02 & 8.91 & 17.50 & 0.22 & 0.27 \\
\hline BG-18-46 & 6 & 11.30 & 37.30 & 0.01 & 2.29 & 32.70 & 0.54 & 0.44 \\
\hline BG-18-47 & 6 & 13.20 & 32.60 & & 4.26 & 34.10 & 0.55 & 0.45 \\
\hline $\mathrm{HC}-18-01$ & 6 & 12.00 & 27.40 & 0.02 & 2.57 & 45.30 & 0.46 & 0.72 \\
\hline HC-18-03 & 6 & 6.56 & 49.00 & 0.01 & 2.75 & 19.70 & 0.28 & 3.33 \\
\hline $\mathrm{HC}-18-04$ & 6 & 15.10 & 8.27 & 2.65 & 1.57 & 62.70 & 0.75 & 0.45 \\
\hline $\mathrm{HC}-18-07$ & 6 & 6.38 & 41.20 & 0.01 & 7.06 & 16.70 & 0.27 & 4.43 \\
\hline HC-18-09 & 6 & 11.40 & 27.10 & - & 3.93 & 43.30 & 0.53 & 0.67 \\
\hline HC-18-12 & 6 & 14.10 & 29.60 & 0.02 & 2.22 & 41.20 & 0.68 & 0.56 \\
\hline $\mathrm{HC}-18-16$ & 6 & 15.70 & 30.60 & 0.10 & 0.33 & 40.20 & 0.96 & 1.00 \\
\hline PYG-18-01 & 6 & 14.40 & 22.10 & 1.14 & 1.40 & 49.70 & 0.68 & 0.46 \\
\hline PYG-18-02 & 6 & 12.00 & 22.70 & 0.56 & 2.04 & 48.20 & 0.44 & 1.19 \\
\hline PYG-18-03 & 6 & 14.30 & 27.80 & 0.86 & 0.75 & 44.90 & 0.72 & 0.65 \\
\hline PYG-18-06 & 6 & 11.00 & 37.70 & 0.03 & 1.33 & 37.50 & 0.54 & 0.57 \\
\hline 101,524 & 7 & 12.50 & 23.90 & 0.22 & 0.81 & 51.30 & 0.72 & 0.10 \\
\hline 101569 & 7 & 11.60 & 38.00 & 0.02 & 2.22 & 34.10 & 0.47 & 0.18 \\
\hline 101570 & 7 & 8.02 & 47.30 & 0.07 & 1.54 & 29.20 & 0.45 & 0.57 \\
\hline 101571 & 7 & 10.00 & 56.00 & 0.12 & 1.15 & 19.40 & 0.49 & 0.30 \\
\hline 101572 & 7 & 5.91 & 69.30 & 0.03 & 1.99 & 12.90 & 0.42 & 0.17 \\
\hline 101573 & 7 & 5.91 & 65.50 & 0.10 & 1.72 & 17.10 & 0.40 & 0.08 \\
\hline 101574 & 7 & 8.58 & 56.00 & 0.05 & 1.68 & 18.50 & 0.62 & 0.08 \\
\hline 101575 & 7 & 5.69 & 55.90 & 0.06 & 1.90 & 24.90 & 0.40 & 0.09 \\
\hline 101576 & 7 & 8.57 & 57.40 & 0.06 & 1.35 & 19.70 & 0.53 & 0.10 \\
\hline BG-18-05 & 7 & 8.81 & 50.50 & 0.03 & 6.02 & 16.80 & 0.37 & 0.35 \\
\hline BG-18-06 & 7 & 7.59 & 63.50 & 0.09 & 0.95 & 17.40 & 0.33 & 0.21 \\
\hline BG-18-07 & 7 & 8.33 & 54.40 & 0.03 & 4.45 & 17.80 & 0.33 & 0.19 \\
\hline BG-18-11 & 7 & 6.92 & 68.00 & 0.03 & 0.88 & 15.90 & 0.29 & 0.47 \\
\hline BG-18-12 & 7 & 5.56 & 70.60 & 0.01 & 2.59 & 11.60 & 0.19 & 0.30 \\
\hline BG-18-16 & 7 & 5.23 & 71.00 & - & 2.68 & 12.40 & 0.21 & 0.30 \\
\hline BG-18-22 & 7 & 7.00 & 62.00 & - & 1.05 & 17.30 & 0.30 & 2.20 \\
\hline BG-18-26 & 7 & 7.99 & 50.30 & 0.01 & 3.35 & 21.40 & 0.30 & 0.88 \\
\hline BG-18-32 & 7 & 6.71 & 48.50 & 0.06 & 7.29 & 20.00 & 0.29 & 0.32 \\
\hline BG-18-35 & 7 & 6.14 & 62.90 & 0.03 & 5.29 & 12.50 & 0.25 & 0.28 \\
\hline BG-18-41 & 7 & 6.70 & 65.70 & - & 1.14 & 14.30 & 0.27 & 0.14 \\
\hline HC-18-17 & 7 & 10.50 & 33.50 & 0.06 & 2.06 & 36.80 & 0.51 & 1.00 \\
\hline
\end{tabular}


sea level cycle (Catuneanu et al., 2011; Couneanu, 2019). Thus, parasequences record smaller scale fluctuations in relative sea level superimposed on longer wavelengths of sea level oscillation.

Outcrop exposures and lithofacies stacking patterns indicate that two laterally correlative parasequences are preserved in the study area (Figure 7). At Betws Garmon, vertical and lateral facies trends are consistent between mine adits along $0.8 \mathrm{~km}$ of depositional strike. With minor variations in facies thickness, these trends are persistent between Betws Garmon, St. Tudwal's Peninsula and Rhiw.

Parasequence 1 is an aggradational ironstone succession that is at least $8 \mathrm{~m}$ thick. This parasequence is interpreted to record a gradual change from distal through middle shelf sedimentation to deposition near fair weather wave base. Basal laminated, organicrich mudstone (F4) accumulated below storm wave base and grades stratigraphically upward into a bioturbated mudstone (F5) that was the locus of intense authigenesis. These mudstones are rich in chamosite and are, in turn, overlain by an intraclastic, $\mathrm{Fe}$ coated grain packstone with locally developed HCS (F6), which records shallowing to just above storm wave base. The top of Parasequence 1 is a trough cross stratified grainstone (F7) reflecting continued aggradation and increased reworking of coated grains near fair weather wave base. Such intense reworking, winnowing, and authigenesis in this chemical sedimentary succession is consistent with stratigraphic condensation in a late transgressive systems tract, suggesting its upper contact is the maximum flooding surface (MFS; Catuneanu et al., 2011; Föllmi, 2016; Catuneanu, 2019).

Parasequence 2 rests sharply on Parasequence 1 and is interpreted to record progradation of clastic middle shelf deposits during early highstand conditions. Unlike Parasequence 1, Parasequence 2 lacks an authigenic overprint and is purely clastic in nature. Parasequence 2 coarsens upward from micaceous shale (F2) and interbedded siltstone (F1), reflecting accumulation below storm wave base, to an HCS sublitharenite (F3) recording deposition between storm and fair weather wave bases. The top of Parasequence 2 is the modern erosion surface.

The link between ironstone deposition and maximum flooding is observed in other Paleozoic ironstones (Young, 1992; Todd et al., 2019; Pufahl et al., 2020). The MFS marks the deepest water facies in a sequence and the change from retrogradational to progradational parasequence stacking (Catuneanu et al., 2011; Catuneanu, 2019). Because the MFS represents the time at which the accommodation is greatest, siliciclastics are trapped in nearshore environments to favour stratigraphic condensation and authigenesis on the distal shelf (Glenn et al., 1994; Taylor and Macquaker, 2000; Pufahl and Groat, 2017). Such low rates of clastic sedimentation stabilize the zone of authigenesis beneath the seafloor (cf. Föllmi, 2016) and permit waves to rework precipitating authigenic muds and coated Fe grains into granular deposits (Todd et al., 2019; Pufahl et al., 2020; Matheson and Frank, 2021).

\section{GEOCHEMISTRY}

Authigenic lithofacies (F5, F6, F7) composing Parasequence 1 contains $\mathrm{Fe}_{2} \mathrm{O}_{3}$ total, $\mathrm{SiO}_{2}$, and $\mathrm{Al}_{2} \mathrm{O}_{3}$ concentrations that total
$>80 \mathrm{wt} \%$ (Table 1), reflecting the abundance of goethite, hematite, chamosite, metamorphic magnetite, and chert. TOC concentrations are highest at the base of Parasequence 1 (F4) with a maximum value of $4.6 \mathrm{wt} \%$ (Table 1). $\mathrm{P}_{2} \mathrm{O}_{5}$ concentrations are greatest in the middle of Parasequence 1 (F2) with values that range between 0.6 and $8.9 \mathrm{wt} \%$ (Table 1). $\mathrm{TiO}_{2}$ and $\mathrm{K}_{2} \mathrm{O}$ concentrations are low and $<1 \mathrm{wt} \%$ through the thickness of this parasequence (Table 1). In siliciclastic facies (F1, F2, F3) of Parasequence 2, $\mathrm{TiO}_{2}$ and $\mathrm{K}_{2} \mathrm{O}$ concentrations are higher than in Parasequence 1 with maximum values of $1.02 \mathrm{wt} \%$ and wt. $3.65 \%$, respectively (Table $\mathbf{1}$ ).

Total REE $+\mathrm{Y}$ concentrations in all lithofacies vary between 178 and $560 \mathrm{ppm}$ Table 2). Authigenic facies (F5, F6, F7) of Parasequence 1 are enriched in middle rare earth elements (MREE) and heavy rare earth elements (HREE). Ce/Ce* and $\mathrm{Eu} / \mathrm{Eu}^{*}$ values in both parasequences range from 0.801 to 1.25 and 0.606 to 1.13 , respectively. True negative $\mathrm{Ce}$ anomalies characterize the base of Parasequence 1 (Figure 8; Bau and Dulski, 1994; Bau et al., 1996; Planavsky et al., 2010). Ce/Ce* and $\mathrm{Pr} / \mathrm{Pr}^{*}$ values in bioturbated chamositic mudstone at the base (F5) range between 0.85 and 0.93 and between 1.06 and 1.13, respectively. Negative Eu anomalies occur in terrigenous clastic (F1, F2) lithofacies and samples of authigenic facies (F5, F6) with a significant detrital component. In samples of authigenic facies (F5, F6) devoid of siliciclastics and containing $\geq 1 \mathrm{wt} \%$ of synsedimentary CFA, minor positive $\mathrm{Eu}$ anomalies are common (Figure 9).

Average concentrations of the redox elements $\mathrm{V}, \mathrm{Cr}$, and $\mathrm{Zn}$ in authigenic facies are $393 \mathrm{ppm}, 163 \mathrm{ppm}$, and $156 \mathrm{ppm}$, respectively, which are significantly higher than shale composite values of $130 \mathrm{ppm}, 125 \mathrm{ppm}$, and $100 \mathrm{pm}$ (Table 3; Morgan et al., 1978; Gromet et al., 1984; Condie, 1993). Other Eh sensitive elements such as Mo, Ni, U are near shale composite values, whereas $\mathrm{Pb}, \mathrm{Co}$, and $\mathrm{Cu}$ are lower (Figure 10; Morgan et al., 1978; Gromet et al., 1984; Condie 1993).

\section{Seawater Redox Conditions and Fe Source}

The REE + Y composition of authigenic facies provide important insights into the presence of oxygen gradients in the Welsh Basin during ironstone accumulation. Because these elements are thought to be relatively immobile during hydrothermal and metamorphic alteration, they are interpreted as a proxy for seawater Eh at the time of deposition (Elderfield and Greaves, 1982; Bau, 1991). The concentration of $\mathrm{REE}+\mathrm{Y}$ in pore water can mimic that of seawater just beneath the seafloor but changes systematically with decreasing $\mathrm{Eh}$ as the pore water system becomes progressively more isolated beneath the sediment-water interface during burial (Haley et al., 2004). MREE-HREE enrichment and a trend towards negative $\mathrm{Ce}$ anomalies through the thickness of Parasequence 1 (F4, F5, F6, F7; Figure 8) support sedimentologic data indicating siliciclastic sediment was trapped in the nearshore, resulting in increased authigenesis in progressively deeper and increasingly anoxic environments away from the coast (Piper et al., 1988; Dubinin, 2004; Bau et al., 2014). 
TABLE 2 | REE + Y concentrations in lithofacies of the Hen-dy-Capel Ironstone Member, Tygarn Formation.

\begin{tabular}{|c|c|c|c|c|c|c|c|c|c|c|c|c|c|c|c|c|}
\hline \multirow[t]{2}{*}{ Sample } & \multirow[t]{2}{*}{ Facies } & \multirow{2}{*}{$\frac{\mathrm{La}}{\mathrm{ppm}}$} & \multirow{2}{*}{$\frac{\mathrm{Ce}}{\mathrm{ppm}}$} & \multirow{2}{*}{$\frac{\mathrm{Pr}}{\mathrm{ppm}}$} & \multirow{2}{*}{$\frac{\text { Nd }}{\text { ppm }}$} & \multirow{2}{*}{$\frac{\mathrm{Sm}}{\mathrm{ppm}}$} & \multirow{2}{*}{$\frac{\mathrm{Eu}}{\mathrm{ppm}}$} & \multirow{2}{*}{$\frac{\text { Gd }}{\text { ppm }}$} & \multirow{2}{*}{$\frac{\mathrm{Tb}}{\mathrm{ppm}}$} & $\mathbf{Y}$ & Dy & Ho & $\mathrm{Er}$ & $\mathrm{Tm}$ & $\mathbf{Y b}$ & Lu \\
\hline & & & & & & & & & & ppm & ppm & ppm & ppm & ppm & ppm & ppm \\
\hline BG-18-04 & 1 & 28.1 & 59.8 & 6.72 & 23.4 & 3.9 & 0.98 & 3.28 & 0.48 & 14.7 & 2.64 & 0.52 & 1.77 & 0.30 & 2.2 & 0.35 \\
\hline HC-18-15 & 1 & 53.5 & 114.0 & 12.40 & 46.2 & 7.8 & 1.42 & 7.16 & 1.08 & 34.4 & 5.99 & 1.22 & 3.61 & 0.49 & 3.4 & 0.51 \\
\hline BG-18-20 & 2 & 47.8 & 104.0 & 12.20 & 48.9 & 10.2 & 2.25 & 10.10 & 1.54 & 51.1 & 8.47 & 1.69 & 4.84 & 0.67 & 4.4 & 0.68 \\
\hline BG-18-27 & 2 & 56.9 & 141.0 & 14.40 & 56.8 & 11.0 & 2.16 & 10.70 & 1.63 & 46.4 & 8.61 & 1.68 & 4.75 & 0.66 & 4.4 & 0.62 \\
\hline HC-18-19 & 2 & 50.2 & 106.0 & 11.10 & 41.0 & 6.9 & 1.16 & 5.58 & 0.88 & 27.4 & 4.96 & 1.01 & 2.91 & 0.41 & 2.9 & 0.42 \\
\hline BG-18-30 & 4 & 57.4 & 135.0 & 14.10 & 57.0 & 11.5 & 2.74 & 11.30 & 1.71 & 52.2 & 9.12 & 1.77 & 4.91 & 0.63 & 4.2 & 0.57 \\
\hline HC-18-18 & 4 & 61.7 & 124.0 & 14.30 & 55.7 & 9.6 & 1.51 & 7.98 & 1.19 & 41.9 & 6.87 & 1.44 & 4.24 & 0.58 & 4.0 & 0.59 \\
\hline BG-18-43 & 4 & 46.6 & 107.0 & 12.80 & 52.0 & 12.2 & 2.56 & 14.70 & 2.38 & 75.9 & 13.80 & 2.73 & 7.41 & 0.99 & 6.4 & 0.90 \\
\hline BG-18-13 & 5 & 33.8 & 75.1 & 9.03 & 39.3 & 10.0 & 2.75 & 13.50 & 2.18 & 82.9 & 12.80 & 2.56 & 7.09 & 0.93 & 5.8 & 0.88 \\
\hline BG-18-24 & 5 & 39.7 & 82.7 & 9.73 & 38.2 & 7.7 & 1.37 & 7.24 & 1.11 & 37.7 & 6.24 & 1.30 & 3.75 & 0.50 & 3.5 & 0.52 \\
\hline BG-18-25 & 5 & 62.2 & 138.0 & 16.00 & 63.9 & 13.6 & 2.61 & 13.70 & 2.20 & 61.8 & 11.80 & 2.29 & 6.11 & 0.79 & 5.2 & 0.71 \\
\hline BG-18-29 & 5 & 50.4 & 129.0 & 12.40 & 50.7 & 10.1 & 1.75 & 9.69 & 1.40 & 45.2 & 7.52 & 1.45 & 4.05 & 0.55 & 3.6 & 0.55 \\
\hline BG-18-38 & 5 & 53.0 & 102.0 & 12.80 & 50.2 & 10.4 & 1.97 & 11.20 & 1.76 & 61.8 & 10.10 & 2.01 & 5.79 & 0.79 & 5.0 & 0.74 \\
\hline BG-18-39 & 5 & 40.4 & 86.0 & 9.81 & 37.7 & 6.4 & 1.03 & 5.61 & 0.84 & 29.5 & 4.84 & 1.02 & 3.21 & 0.45 & 3.0 & 0.46 \\
\hline BG-18-40 & 5 & 45.4 & 92.0 & 11.00 & 44.4 & 9.2 & 2.04 & 9.98 & 1.53 & 51.7 & 8.66 & 1.72 & 4.82 & 0.65 & 4.1 & 0.61 \\
\hline BG-18-45 & 5 & 58.6 & 126.0 & 15.00 & 59.8 & 12.3 & 2.20 & 12.70 & 2.04 & 63.2 & 10.90 & 2.23 & 6.08 & 0.81 & 5.4 & 0.76 \\
\hline HC-18-08 & 5 & 41.9 & 85.5 & 9.72 & 35.8 & 4.9 & 0.53 & 3.31 & 0.57 & 22.6 & 3.65 & 0.79 & 2.64 & 0.39 & 2.9 & 0.46 \\
\hline PYG-18-07 & 5 & 51.5 & 115.0 & 12.30 & 46.4 & 7.3 & 1.27 & 6.69 & 1.09 & 39.5 & 6.70 & 1.38 & 4.46 & 0.66 & 4.8 & 0.73 \\
\hline BG-18-01-A & 6 & 45.9 & 125.0 & 11.60 & 48.6 & 11.0 & 2.59 & 12.40 & 2.07 & 74.6 & 11.70 & 2.39 & 6.94 & 0.92 & 5.8 & 0.86 \\
\hline BG-18-14 & 6 & 47.2 & 98.8 & 11.60 & 45.4 & 9.5 & 2.03 & 10.20 & 1.61 & 54.3 & 8.79 & 1.79 & 4.87 & 0.67 & 4.4 & 0.62 \\
\hline BG-18-15 & 6 & 41.8 & 86.9 & 9.99 & 42.6 & 9.7 & 2.52 & 11.30 & 1.73 & 58.3 & 9.49 & 1.86 & 5.20 & 0.67 & 4.2 & 0.60 \\
\hline BG-18-23 & 6 & 55.6 & 113.0 & 14.40 & 60.4 & 14.1 & 3.36 & 16.50 & 2.73 & 98.4 & 15.50 & 3.13 & 8.37 & 1.12 & 6.8 & 0.93 \\
\hline BG-18-28 & 6 & 42.7 & 112.0 & 11.00 & 44.7 & 9.0 & 1.68 & 9.54 & 1.53 & 46.4 & 8.83 & 1.75 & 4.86 & 0.66 & 4.7 & 0.66 \\
\hline BG-18-31 & 6 & 75.7 & 154.0 & 19.70 & 81.0 & 18.5 & 3.56 & 20.80 & 3.34 & 116.0 & 18.80 & 3.70 & 9.95 & 1.30 & 7.8 & 1.08 \\
\hline BG-18-34b & 6 & 41.9 & 87.1 & 10.20 & 39.5 & 7.7 & 1.40 & 7.52 & 1.18 & 37.8 & 6.58 & 1.26 & 3.75 & 0.50 & 3.4 & 0.53 \\
\hline BG-18-37 & 6 & 44.0 & 93.5 & 11.80 & 50.0 & 12.5 & 3.36 & 15.60 & 2.55 & 108.0 & 15.10 & 3.13 & 8.76 & 1.16 & 7.1 & 1.01 \\
\hline BG-18-46 & 6 & 65.3 & 136.0 & 16.50 & 66.2 & 14.0 & 2.98 & 15.40 & 2.49 & 83.7 & 14.10 & 2.84 & 7.74 & 1.08 & 6.8 & 0.96 \\
\hline BG-18-47 & 6 & 63.7 & 132.0 & 17.30 & 72.4 & 17.5 & 3.60 & 19.60 & 3.09 & 104.0 & 17.50 & 3.38 & 9.27 & 1.24 & 7.4 & 0.99 \\
\hline HC-18-01 & 6 & 57.0 & 117.0 & 14.00 & 56.5 & 13.0 & 3.36 & 15.90 & 2.52 & 84.7 & 13.50 & 2.76 & 7.54 & 0.99 & 6.0 & 0.86 \\
\hline HC-18-03 & 6 & 42.6 & 76.0 & 10.10 & 40.4 & 9.0 & 2.38 & 11.40 & 1.89 & 68.1 & 10.50 & 2.16 & 5.85 & 0.77 & 4.7 & 0.66 \\
\hline HC-18-04 & 6 & 53.0 & 129.0 & 13.50 & 57.1 & 13.9 & 3.27 & 16.40 & 2.51 & 73.0 & 12.90 & 2.48 & 6.54 & 0.84 & 5.4 & 0.77 \\
\hline HC-18-07 & 6 & 48.4 & 84.1 & 12.10 & 56.4 & 14.1 & 3.67 & 16.80 & 2.53 & 97.6 & 14.00 & 2.76 & 7.32 & 0.88 & 5.5 & 0.75 \\
\hline HC-18-09 & 6 & 45.7 & 98.2 & 11.70 & 51.2 & 12.4 & 3.11 & 13.90 & 2.13 & 65.2 & 11.50 & 2.15 & 5.62 & 0.72 & 4.7 & 0.67 \\
\hline HC-18-12 & 6 & 66.2 & 143.0 & 16.20 & 61.9 & 12.6 & 2.71 & 14.50 & 2.38 & 77.0 & 13.50 & 2.69 & 7.38 & 0.99 & 6.4 & 0.92 \\
\hline HC-18-16 & 6 & 60.3 & 120.0 & 13.90 & 50.2 & 6.5 & 1.10 & 5.15 & 0.82 & 35.2 & 5.18 & 1.18 & 3.93 & 0.60 & 4.2 & 0.64 \\
\hline PYG-18-01 & 6 & 51.0 & 124.0 & 12.90 & 52.9 & 12.2 & 2.81 & 12.70 & 2.01 & 63.1 & 11.40 & 2.25 & 6.15 & 0.84 & 5.3 & 0.83 \\
\hline PYG-18-02 & 6 & 39.1 & 94.0 & 10.80 & 48.2 & 14.2 & 3.27 & 16.60 & 2.53 & 76.1 & 13.90 & 2.70 & 7.38 & 0.98 & 6.4 & 0.94 \\
\hline PYG-18-03 & 6 & 43.1 & 94.4 & 10.00 & 38.0 & 7.2 & 1.60 & 7.51 & 1.22 & 39.8 & 7.04 & 1.43 & 4.21 & 0.60 & 4.1 & 0.63 \\
\hline PYG-18-06 & 6 & 43.0 & 96.7 & 10.60 & 41.4 & 8.9 & 1.93 & 9.57 & 1.62 & 52.2 & 9.09 & 1.88 & 5.20 & 0.76 & 4.8 & 0.72 \\
\hline 101524 & 7 & 56.6 & 134.0 & 15.40 & 64.2 & 14.6 & 3.47 & 15.30 & 2.55 & 74.7 & 14.40 & 2.90 & 8.28 & 1.21 & 7.9 & 1.15 \\
\hline 101569 & 7 & 29.7 & 69.0 & 8.32 & 33.7 & 7.7 & 1.61 & 7.77 & 1.30 & 41.1 & 7.80 & 1.53 & 4.28 & 0.65 & 4.4 & 0.62 \\
\hline 101570 & 7 & 48.1 & 104.0 & 13.40 & 56.4 & 13.3 & 2.84 & 15.10 & 2.55 & 85.5 & 14.80 & 2.92 & 8.23 & 1.11 & 7.3 & 1.07 \\
\hline 101571 & 7 & 37.2 & 96.1 & 11.00 & 47.1 & 12.2 & 2.79 & 13.90 & 2.50 & 75.7 & 15.30 & 3.06 & 8.79 & 1.27 & 8.6 & 1.23 \\
\hline 101572 & 7 & 42.2 & 101.0 & 11.30 & 46.9 & 11.3 & 2.53 & 12.30 & 2.08 & 60.3 & 12.40 & 2.47 & 7.01 & 1.01 & 6.7 & 0.97 \\
\hline 101573 & 7 & 45.2 & 117.0 & 13.40 & 57.6 & 14.2 & 3.22 & 16.40 & 2.78 & 80.8 & 16.60 & 3.35 & 9.83 & 1.40 & 9.5 & 1.36 \\
\hline 101574 & 7 & 35.8 & 92.6 & 11.00 & 47.2 & 11.7 & 2.77 & 13.80 & 2.42 & 74.5 & 14.50 & 2.95 & 8.66 & 1.25 & 8.4 & 1.19 \\
\hline 101575 & 7 & 56.0 & 134.0 & 15.20 & 62.3 & 14.1 & 3.25 & 15.50 & 2.53 & 74.3 & 14.70 & 2.89 & 8.51 & 1.22 & 8.3 & 1.17 \\
\hline 101576 & 7 & 43.9 & 112.0 & 12.80 & 55.4 & 13.5 & 2.91 & 15.50 & 2.66 & 80.9 & 15.80 & 3.18 & 9.29 & 1.36 & 9.1 & 1.34 \\
\hline BG-18-05 & 7 & 75.6 & 161.0 & 20.30 & 84.5 & 20.9 & 4.89 & 25.70 & 4.24 & 147.0 & 23.80 & 4.82 & 13.00 & 1.75 & 10.6 & 1.51 \\
\hline BG-18-06 & 7 & 31.9 & 78.7 & 9.25 & 37.9 & 8.5 & 1.85 & 9.53 & 1.55 & 49.0 & 8.91 & 1.79 & 4.94 & 0.65 & 4.4 & 0.62 \\
\hline BG-18-07 & 7 & 97.6 & 220.0 & 26.40 & 109.0 & 22.9 & 4.49 & 25.20 & 4.00 & 126.0 & 22.00 & 4.32 & 11.80 & 1.56 & 9.8 & 1.40 \\
\hline BG-18-11 & 7 & 46.8 & 110.0 & 12.60 & 52.2 & 11.6 & 2.55 & 13.30 & 2.22 & 66.0 & 12.10 & 2.37 & 6.41 & 0.85 & 5.4 & 0.75 \\
\hline BG-18-12 & 7 & 41.2 & 94.3 & 11.10 & 45.9 & 11.1 & 2.34 & 13.40 & 2.34 & 83.5 & 13.50 & 2.77 & 8.02 & 1.09 & 7.1 & 0.98 \\
\hline BG-18-16 & 7 & 39.1 & 91.5 & 10.80 & 45.3 & 11.4 & 2.35 & 13.20 & 2.26 & 81.7 & 13.00 & 2.69 & 7.43 & 1.03 & 6.5 & 0.93 \\
\hline BG-18-22 & 7 & 46.9 & 99.2 & 12.20 & 48.2 & 10.7 & 2.44 & 12.00 & 1.88 & 57.1 & 10.60 & 1.99 & 5.46 & 0.74 & 4.7 & 0.66 \\
\hline BG-18-26 & 7 & 70.4 & 157.0 & 19.10 & 81.5 & 19.5 & 4.24 & 22.90 & 3.77 & 129.0 & 21.50 & 4.31 & 12.00 & 1.54 & 9.7 & 1.36 \\
\hline BG-18-32 & 7 & 57.6 & 124.0 & 15.40 & 66.5 & 17.0 & 4.30 & 20.70 & 3.41 & 131.0 & 19.80 & 3.91 & 11.00 & 1.43 & 8.9 & 1.26 \\
\hline BG-18-35 & 7 & 56.9 & 126.0 & 15.40 & 65.5 & 16.3 & 3.80 & 20.60 & 3.44 & 137.0 & 20.40 & 4.17 & 11.60 & 1.57 & 9.6 & 1.37 \\
\hline BG-18-41 & 7 & 39.6 & 88.6 & 10.50 & 41.6 & 9.0 & 2.15 & 10.10 & 1.62 & 53.2 & 9.19 & 1.83 & 4.94 & 0.68 & 4.4 & 0.63 \\
\hline HC-18-17 & 7 & 53.8 & 111.0 & 13.30 & 52.1 & 10.9 & 2.36 & 12.20 & 1.93 & 64.1 & 10.80 & 2.09 & 6.01 & 0.78 & 5.0 & 0.73 \\
\hline
\end{tabular}




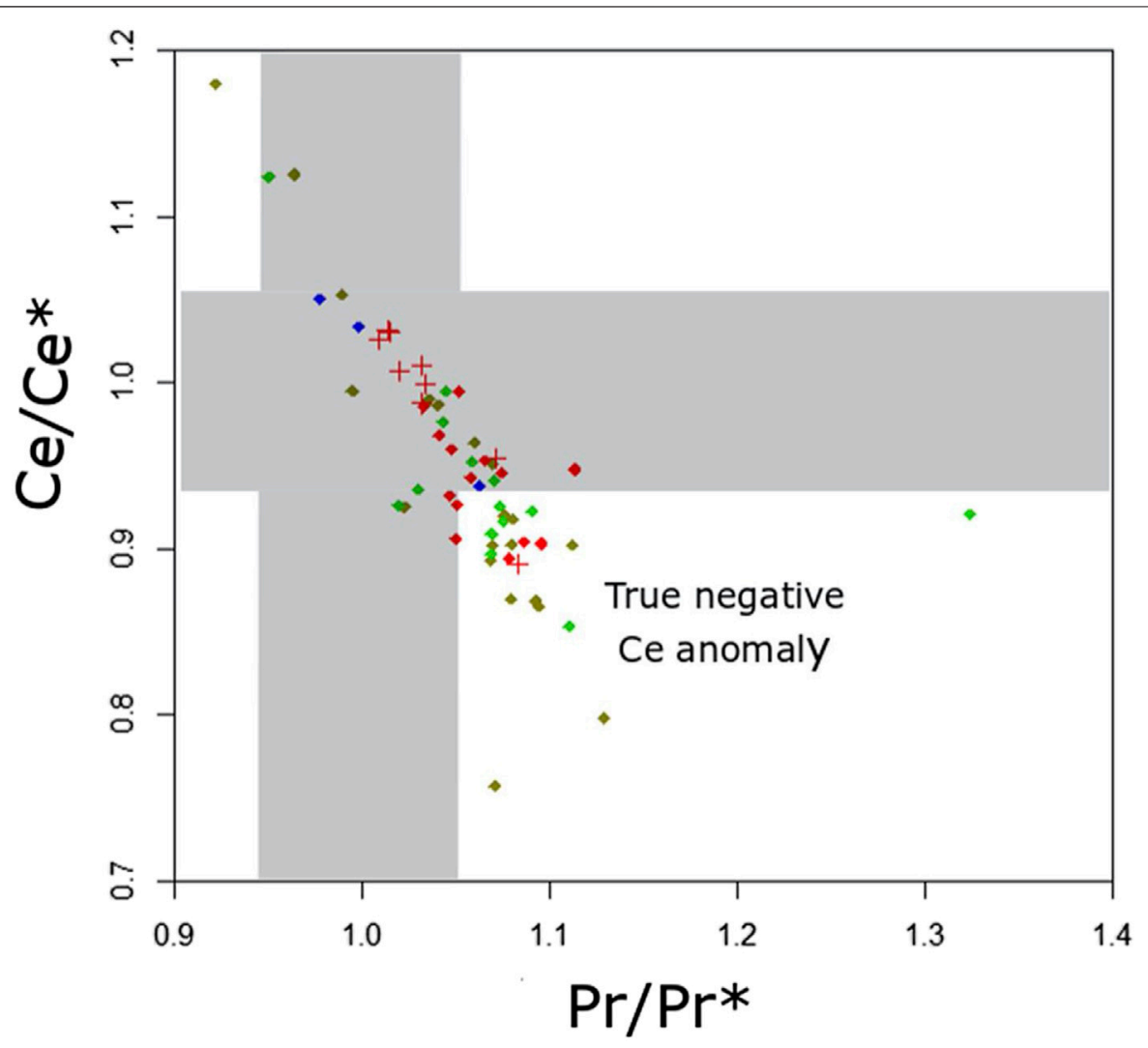

FIGURE 8|Plot of Ce and Pr anomalies. Grey areas indicate no true anomaly (Bau and Dulski, 1994; Planavsky et al., 2010). Colours reflect facies: blue = clastic rich F1 and F3, green = F5, brown = F6, red = F7, red crosses = F7 from drill core. 'True' Ce anomalies are defined by Ce versus Pr values above and below unity, discriminating between positive La and true negative Ce anomalies as described by Bau and Dulski (1994).

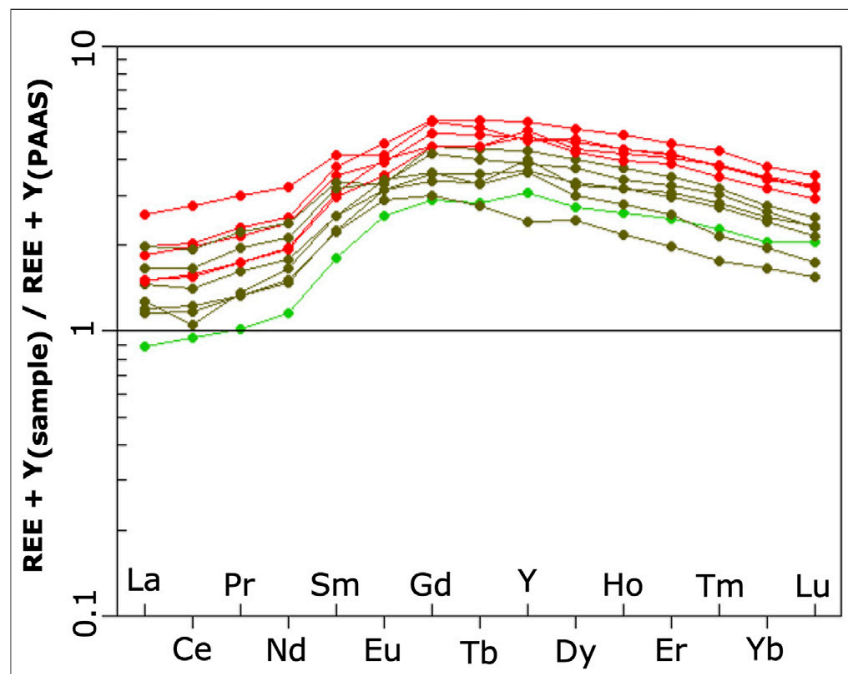

FIGURE 9 |PAAS-normalized REE distribution of P-rich samples (>3 wt \%) from Welsh Basin ironstone (Table 2). Colours reflect facies: blue = clastic rich $\mathrm{F} 1$ and $\mathrm{F} 3$, green $=F 5$, brown $=F 6$, red $=F 7$, red crosses $=F 7$ from drill core.
On the middle shelf, oxidative scavenging by synsedimentary Fe-(oxyhydr)oxides removed $\mathrm{Ce}$ from seawater producing a negative Ce anomaly in CFA-rich facies (F6, F7; Elderfield and Greaves, 1982; Bau, 1991; Ohta and Kawabe, 2001). Authigenic CFA readily incorporates REEs during precipitation, passively recording the contemporary seawater signature to chemical sediments accumulating away from the direct influence of terrigenous clastic input (Jarvis et al., 1994; Watkins et al., 1995). The enrichment of MREEs and HREEs in CFA-rich facies probably reflects the preferential removal of the other light rare earth elements (LREE), which are scavenged compared to the heavier REEs due to their lower stability in seawater Ce (Jarvis et al., 1994).

Minor positive Eu anomalies in chamosite- and phosphaterich authigenic facies (F5, F6) suggest ironstone deposition was fueled by the delivery of anoxic seawater enriched in hydrothermally derived Fe (McLennan, 1989; Derry and Jacobsen, 1990; Danielson et al., 1992; Erel and Stolper, 1993; Klein, 2005; Hannigan et al., 2010). At mid-ocean ridges, $\mathrm{Eu}$ is reduced during the alteration of basalt resulting in decreased sorption of $\mathrm{Eu}^{2+}$ compared to $\mathrm{Eu}^{3+}$, producing discharging fluids enriched in total Eu (Danielson 
TABLE 3 | Trace metal concentrations + Fe in lithofacies of the Hen-dy-Capel Ironstone Member, Tygarn Formation.

\begin{tabular}{|c|c|c|c|c|c|c|c|c|c|c|c|}
\hline \multirow[t]{2}{*}{ Sample } & \multirow[t]{2}{*}{ Facies } & \multirow{2}{*}{$\begin{array}{c}\mathrm{Fe} \\
\%\end{array}$} & \multirow{2}{*}{$\frac{\mathrm{Cr}}{\mathrm{ppm}}$} & \multirow{2}{*}{$\frac{\mathrm{V}}{\mathrm{ppm}}$} & \multirow{2}{*}{$\frac{\mathrm{Zn}}{\mathrm{ppm}}$} & \multirow{2}{*}{$\frac{\text { Mo }}{\text { ppm }}$} & \multirow{2}{*}{$\frac{\mathrm{Ni}}{\mathrm{ppm}}$} & \multirow{2}{*}{$\frac{U}{\text { ppm }}$} & \multirow{2}{*}{$\frac{\mathrm{Pb}}{\mathrm{ppm}}$} & \multirow{2}{*}{$\frac{\text { Co }}{\text { ppm }}$} & \multirow{2}{*}{$\frac{\mathrm{Cu}}{\mathrm{ppm}}$} \\
\hline & & & & & & & & & & & \\
\hline BG-18-04 & 1 & 40.00 & 150 & 336 & 109 & 5 & 46 & 2.43 & 18 & 5.2 & 44 \\
\hline HC-18-15 & 1 & 17.00 & 200 & 378 & 124 & 7 & 34 & 3.98 & 7 & 19.9 & 11 \\
\hline BG-18-20 & 2 & 26.30 & 190 & 371 & 146 & 5 & 35 & 2.70 & 10 & 8.9 & 16 \\
\hline BG-18-27 & 2 & 33.10 & 190 & 481 & 110 & 7 & 46 & 2.62 & 8 & 19.9 & 5 \\
\hline HC-18-19 & 2 & 38.30 & 100 & 347 & 140 & 3 & 39 & 2.56 & 6 & 18.5 & 13 \\
\hline BG-18-30 & 4 & 49.00 & 180 & 470 & 52 & 7 & 40 & 2.36 & 8 & 17.2 & 46 \\
\hline HC-18-18 & 4 & 44.40 & 120 & 361 & 60 & 4 & 35 & 2.07 & 7 & 5.0 & 9 \\
\hline BG-18-43 & 4 & 25.30 & 250 & 358 & 169 & 10 & 60 & 2.61 & 55 & 8.0 & 8 \\
\hline BG-18-13 & 5 & 40.40 & 140 & 352 & 104 & 5 & 55 & 2.39 & - & 30.0 & 156 \\
\hline BG-18-24 & 5 & 38.50 & 160 & 389 & 121 & 5 & 34 & 2.32 & 9 & 14.1 & - \\
\hline BG-18-25 & 5 & 37.40 & 120 & 353 & 114 & 2 & 45 & 2.70 & - & 4.7 & 5 \\
\hline BG-18-29 & 5 & 19.80 & 150 & 208 & 194 & 3 & 64 & 2.17 & 9 & 32.3 & 23 \\
\hline BG-18-38 & 5 & 34.80 & 210 & 677 & 188 & - & 51 & 4.40 & 13 & 5.3 & 21 \\
\hline BG-18-39 & 5 & 44.20 & 270 & 550 & 194 & 10 & 59 & 1.85 & 13 & 6.7 & 6 \\
\hline BG-18-40 & 5 & 36.50 & 160 & 437 & 206 & 4 & 76 & 3.80 & 8 & 11.5 & 30 \\
\hline BG-18-45 & 5 & 46.40 & 210 & 736 & 145 & 5 & 64 & 1.77 & 5 & 7.1 & 11 \\
\hline HC-18-08 & 5 & $>50$ & 230 & 707 & 256 & 5 & 45 & 3.61 & 6 & 29.3 & 9 \\
\hline PYG-18-07 & 5 & 46.00 & 100 & 273 & 731 & 5 & 96 & 9.52 & 22 & 24.7 & 16 \\
\hline BG-18-01-A & 6 & 21.90 & 180 & 411 & 105 & 16 & 25 & 2.65 & 10 & 15.0 & 28 \\
\hline BG-18-14 & 6 & 30.60 & 200 & 258 & 463 & 13 & 39 & 2.61 & 15 & 6.6 & 47 \\
\hline BG-18-15 & 6 & 47.00 & 180 & 568 & 70 & 2 & 27 & 2.73 & 6 & 19.9 & 118 \\
\hline BG-18-23 & 6 & 19.30 & 290 & 334 & 221 & 11 & 43 & 3.09 & - & 6.0 & 40 \\
\hline BG-18-28 & 6 & 42.90 & 200 & 661 & 106 & 3 & 27 & 2.32 & - & 9.5 & 18 \\
\hline BG-18-31 & 6 & 23.00 & 160 & 425 & 90 & 5 & 27 & 3.37 & - & 8.0 & 8 \\
\hline BG-18-34b & 6 & 26.90 & 120 & 270 & 130 & 6 & 74 & 2.37 & - & 16.6 & 23 \\
\hline BG-18-37 & 6 & 26.10 & 130 & 404 & 100 & - & 36 & 2.71 & - & 4.5 & 16 \\
\hline BG-18-46 & 6 & 34.30 & 210 & 946 & 74 & - & 34 & 5.31 & - & 9.0 & 100 \\
\hline BG-18-47 & 6 & 22.90 & 140 & 343 & 142 & - & 53 & 2.86 & 7 & 3.6 & 38 \\
\hline HC-18-01 & 6 & 30.70 & 170 & 518 & 126 & - & 29 & 2.29 & - & 9.3 & 210 \\
\hline HC-18-03 & 6 & 22.80 & 120 & 184 & 158 & - & 73 & 3.98 & - & 11.0 & 10 \\
\hline HC-18-04 & 6 & 10.10 & 170 & 215 & 88 & 6 & 40 & 3.00 & 51 & 42.3 & 74 \\
\hline HC-18-07 & 6 & 25.00 & 170 & 322 & 160 & - & 46 & 2.98 & - & 5.2 & 13 \\
\hline HC-18-09 & 6 & 34.30 & 160 & 568 & 188 & 2 & 33 & 4.47 & 13 & 12.5 & 8 \\
\hline HC-18-12 & 6 & 27.50 & 120 & 297 & 121 & 3 & 45 & 1.96 & 6 & 10.6 & 8 \\
\hline HC-18-16 & 6 & 42.60 & 190 & 678 & 88 & 3 & 28 & 4.48 & 13 & 15.2 & 21 \\
\hline PYG-18-01 & 6 & 35.90 & 230 & 343 & 70 & 10 & 23 & 5.78 & 15 & 9.5 & 33 \\
\hline PYG-18-02 & 6 & 21.60 & 130 & 314 & 220 & - & 35 & 3.29 & 8 & 4.8 & 42 \\
\hline PYG-18-03 & 6 & 25.50 & 130 & 284 & 164 & 3 & 59 & 2.34 & - & 15.4 & 31 \\
\hline PYG-18-06 & 6 & 25.00 & 140 & 342 & 273 & 2 & 44 & 2.34 & 5 & 15.1 & 32 \\
\hline 101524 & 7 & 45.60 & 150 & 542 & 224 & 4 & 34 & 1.83 & - & 19.9 & - \\
\hline 101569 & 7 & 38.20 & 230 & 738 & 87 & 4 & 38 & 2.04 & - & 19.2 & 36 \\
\hline 101570 & 7 & 25.30 & 140 & 462 & 159 & - & 35 & 2.72 & 6 & 14.3 & 25 \\
\hline 101571 & 7 & 26.30 & 180 & 598 & 205 & 3 & 29 & 3.97 & 11 & 33.5 & - \\
\hline 101572 & 7 & 23.50 & 140 & 332 & 165 & - & 20 & 3.33 & 19 & 32.6 & - \\
\hline 101573 & 7 & 20.50 & 170 & 352 & 169 & 3 & 46 & 2.62 & 52 & 20.2 & - \\
\hline 101574 & 7 & 33.80 & 100 & 287 & 101 & - & 32 & 1.96 & 21 & 22.3 & - \\
\hline 101575 & 7 & 5.82 & 140 & 171 & 114 & 4 & 63 & 3.78 & 206 & 25.6 & - \\
\hline 101576 & 7 & 30.30 & 100 & 175 & 94 & 3 & 25 & 3.88 & 25 & 18.7 & 13 \\
\hline BG-18-05 & 7 & 24.80 & 100 & 240 & 146 & 3 & 53 & 3.76 & 16 & 8.2 & 35 \\
\hline BG-18-06 & 7 & 18.90 & 120 & 248 & 114 & 3 & 43 & 2.92 & 98 & 14.9 & 27 \\
\hline BG-18-07 & 7 & 21.20 & 180 & 416 & 124 & 6 & 57 & 3.08 & 22 & 16.9 & 51 \\
\hline BG-18-11 & 7 & 21.70 & 120 & 300 & 200 & 3 & 77 & 2.51 & 65 & 13.4 & 32 \\
\hline BG-18-12 & 7 & 22.30 & 150 & 393 & 166 & - & 58 & 3.55 & 71 & 6.2 & 43 \\
\hline BG-18-16 & 7 & 24.20 & 160 & 391 & 136 & - & 42 & 2.67 & 41 & 5.0 & 6 \\
\hline BG-18-22 & 7 & 14.40 & 140 & 181 & 104 & 98 & 51 & 3.35 & 152 & 6.5 & 8 \\
\hline BG-18-26 & 7 & 9.75 & 120 & 136 & 119 & 4 & 58 & 2.43 & 6 & 11.2 & 35 \\
\hline BG-18-32 & 7 & 15.40 & 140 & 215 & 132 & 4 & 54 & 3.18 & 52 & 7.4 & 18 \\
\hline BG-18-35 & 7 & 15.70 & 250 & 362 & 149 & 7 & 37 & 2.52 & 68 & 5.6 & - \\
\hline BG-18-41 & 7 & 19.40 & 150 & 264 & 156 & 5 & 62 & 2.95 & 60 & 7.4 & 17 \\
\hline HC-18-17 & 7 & 21.70 & 120 & 294 & 191 & 2 & 67 & 3.75 & 21 & 13.8 & 32 \\
\hline
\end{tabular}




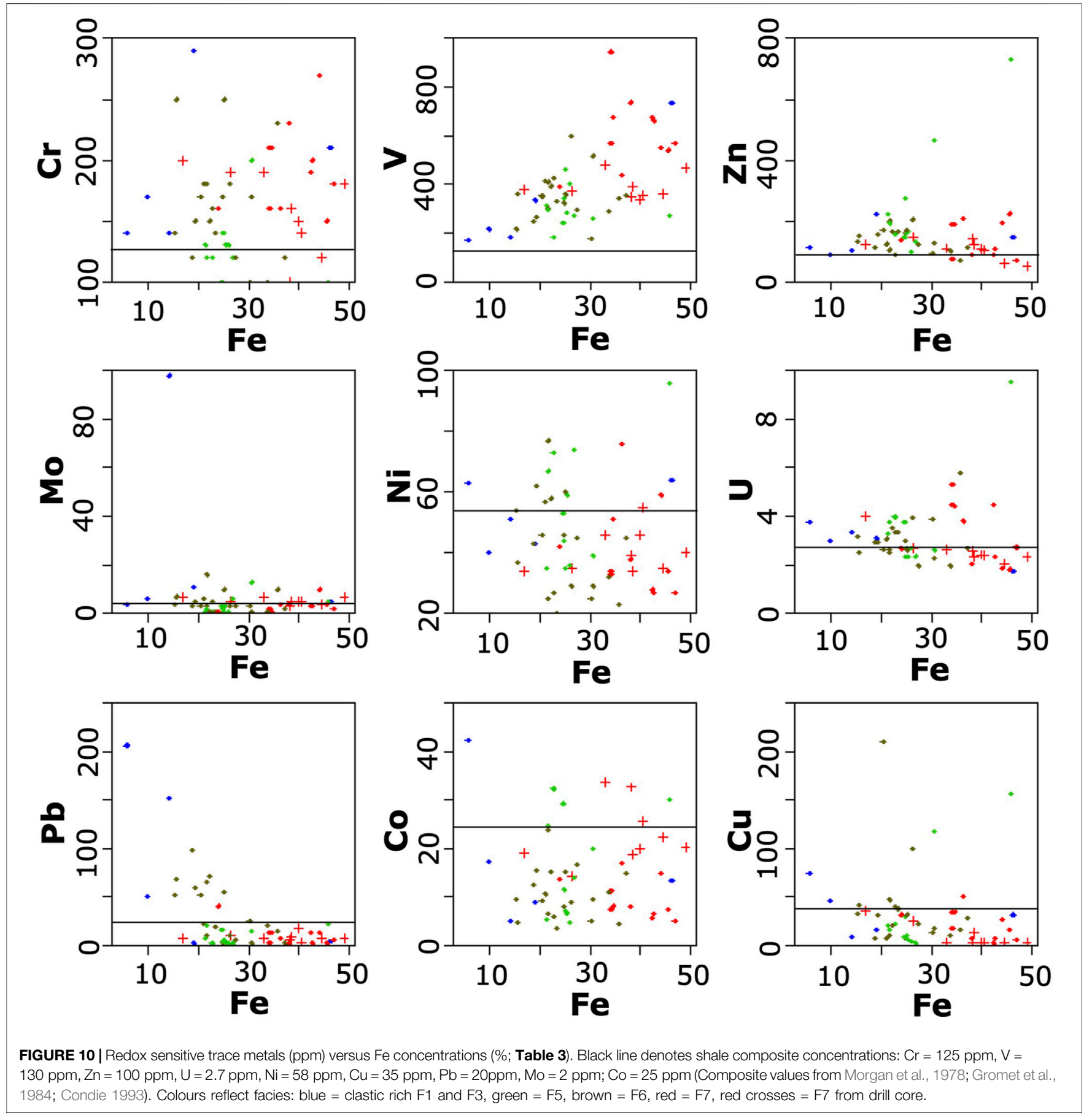

et al., 1992; Klein, 2005). In oxidizing environments away from the vent, $\mathrm{Eu}$ is scavenged by precipitating $\mathrm{Fe}$-(oxyhydr)oxide to produce a positive Eu anomaly in accumulating authigenic Fe deposits. Because Eu anomalies are not produced by other $\mathrm{REE}+\mathrm{Y}$ sources they are considered a robust indicator of hydrothermal input (Derry and Jacobsen, 1990; Olivarez and Owen, 1991; Danielson et al., 1992; Bau and Dulski, 1999; Bayon et al., 2015). The opening Rheic Ocean was ideal for the production and ponding of hydrothermally derived ferruginous seawater (Figure 11; Todd et al., 2019; Pufahl et al., 2020). Mid-ocean ridges discharged hydrothermal Fe as Avalonia rifted from Gondwana. Areas of early back-arc extension in the Welsh Basin may have locally increased this supply of hydrothermal Fe (Kokelaar et al., 1984; Woodcock, 1990; Brenchley et al., 2006; Howells, 2007). Sluggish seawater exchange in this narrow seaway is thought to have allowed anoxic bottom water to develop and transport Fe away from areas of active spreading. 

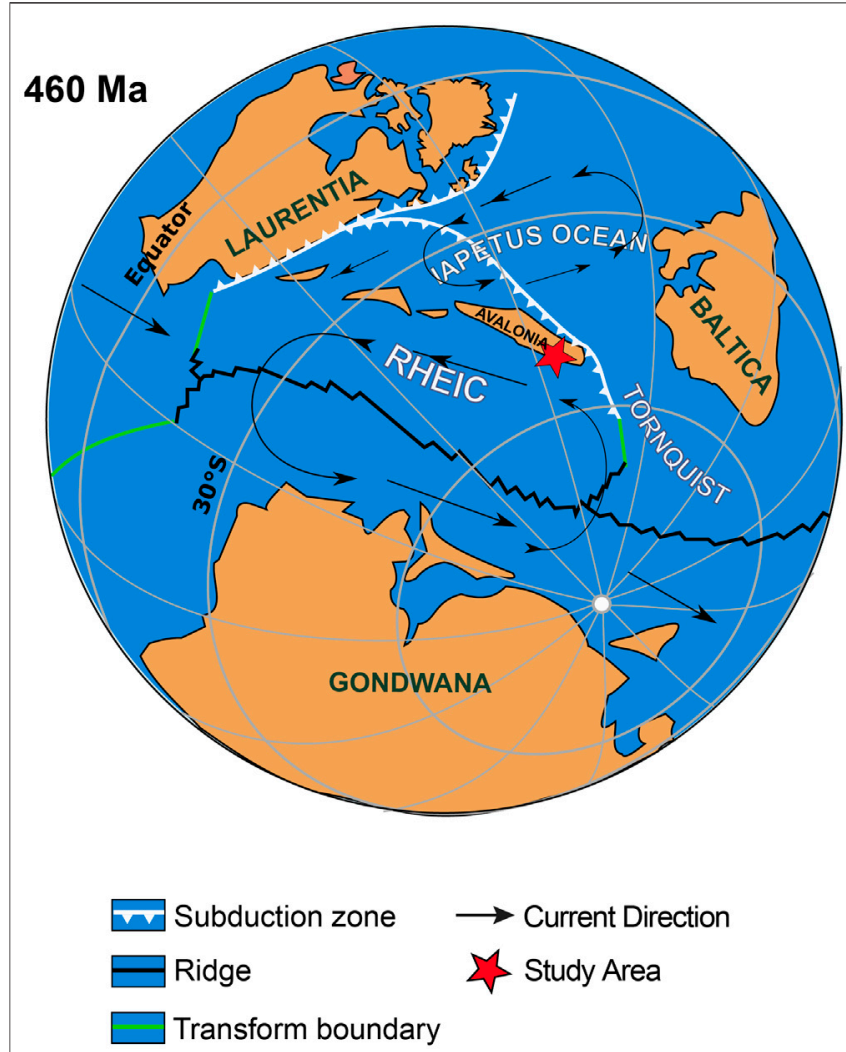

FIGURE 11 | Paleogeography of the Middle Ordovician. Global dispersal of continents and major oceans with paleo surface currents (modified from Torsvik and Cocks, 2013; Pohl et al., 2016).

The delivery of ferruginous seawater to continental shelves via coastal upwelling is analogous to the Precambrian when widespread anoxia allowed hydrothermal Fe to concentrate in the global ocean (Pufahl et al., 2020; Matheson and Pufahl, 2021). In the Neoarchean and Paleoproterozoic, the combination of a large $\mathrm{Fe}$ reservoir that was periodically tapped by upwelling along favourably positioned continents produced aerially extensive iron formations (Gross, 1983; Bekker et al., 2010; Pufahl, 2010; Pufahl et al., 2020). These continental margin iron formations are the largest iron deposits on Earth. More pronounced positive $\mathrm{Eu}$ anomalies in continental margin iron formations are generally attributed to the lack of contamination by siliciclastics (Danielson et al., 1992), which is common in less voluminous, Phanerozoic ironstones (Van Houten and Bhattacharyya, 1982; Van Houten and Arthur, 1989; Pufahl, 2010). Fe-redox pumping in sediment (Heggie et al., 1990; Jarvis et al., 1994) may have further muted Eu anomalies. With enough time, the cyclic scavenging and release of REEs adsorbed onto $\mathrm{Fe}$-(oxyhydr) oxides restores pore water REE ratios to near shale values (Derry and Jacobsen, 1990; Planavsky et al., 2010).

\section{Paleozoic Plume-Related Magmatism and Hydrothermal Fe}

Geodynamic models predict that plume-related magmatism should preferentially occur along the margins of Gondwana in the aftermath of Late Neoproterozoic Pan-African continental collisions that resulted in its amalgamation (Murphy et al., 2021; Wang et al., 2021). Although Rheic oceanic lithosphere has been largely destroyed by subduction, there are several examples in which independent studies identify plume-related magmatism in Cambrian-Ordovician successions on both flanks of this ocean. Along its northern flank, these examples include mid-to-late Cambrian alkalic basalts (Greenough and Papezik, 1985; Murphy et al., 1985) in Avalonian rocks of Atlantic Canada. Such magmatism may have heralded the onset of rifting that led to Rheic Ocean development and input of hydrothermal Fe in this

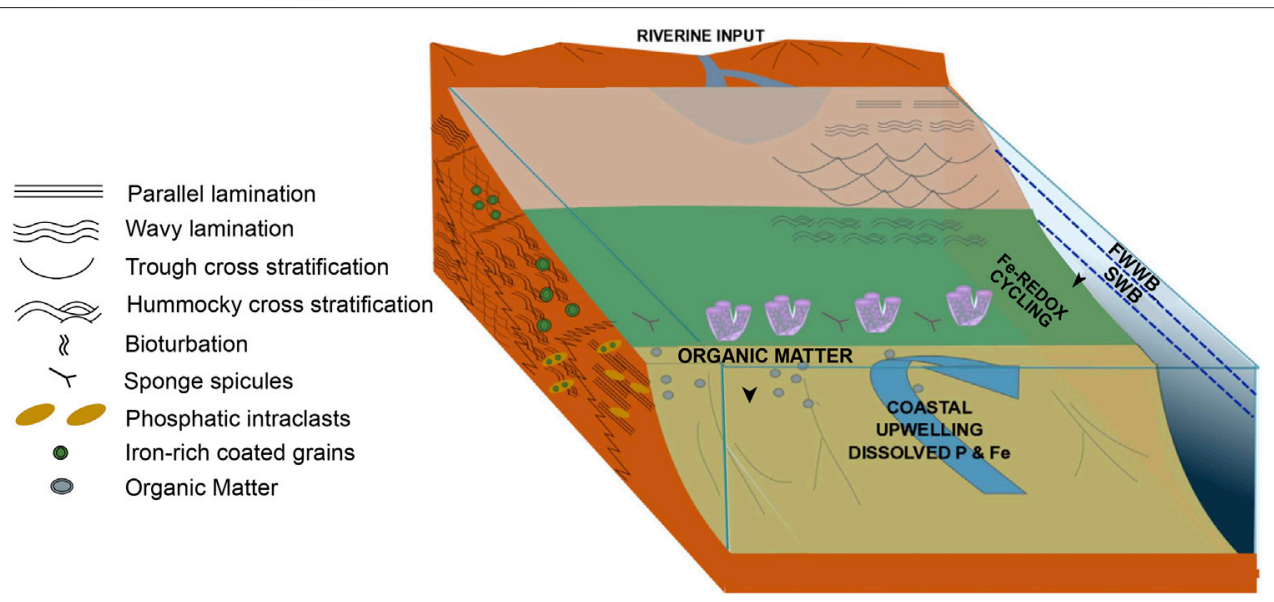

FIGURE 12|Depositional model for Welsh Basin ironstone. Coastal upwelling provides micronutrients Fe and $\mathrm{P}$ to the shelf stimulating primary productivity and the food source of filter feeding sponges on the shelf. Fe-redox cycling on the shelf concentrates the nutrients in the sediment, with redox conditions and hydrodynamics as the primary control of facies distributions. A riverine source for terrigenous clastics is inferred. FWWB, fair-weather wave base; SWB, storm wave base. Modified from Todd et al. (2019). 
narrow seaway (Figure 11; e.g., Nance et al., 2010). Along its southern flank, examples include late Cambrian-early Ordovician alkalic mafic magmatism in the Ossa Morena Zone of Iberia (Sánchez-García et al., 2003, 2008) and the 495-470 Ma voluminous magmatism of the Ollo de Sapo "formation". The Ollo de Sapo "formation" is recognized in every major Variscan massif, and palinspastic reconstructions suggest it extended for as much as 2,000 km along the north African margin (Montero et al., 2009; Talavera et al., 2015; Gutiérrez-Alonso et al., 2016; Casas and Murphy 2018; García-Arias et al., 2018). The ca. $530 \mathrm{Ma}$ Blovice complex of the Bohemian Massif is interpreted as a collage of oceanic arcs, with a mantle plume located beneath a spreading ridge in a back-arc basin (Ackerman et al., 2019).

\section{DEPOSITIONAL MODEL}

Lithofacies associations in the Hen-dy-Capel Ironstone Member are interpreted to record ironstone accumulation along the northern margin of the Rheic Ocean on a storm-dominated shelf with active coastal upwelling (Figure 12). Organic-rich mudstone, phosphatic nodules, and biogenic silica (F4, F5, F6, F7) are diagnostic of upwelling environments and a productive surface ocean (Jahnke et al., 1983; Behl and Garrison, 1994; Glenn et al., 1994; Sharp, 2007; Föllmi, 1996; Pufahl and Groat, 2017). Modern upwelling systems such as the Humboldt and Benguela current regions along the coasts of Peru and southern Africa, respectively, are characterized by this triad of sedimentary deposits (Suess and Von Huene, 1990; Wefer et al., 2002). Modelling of surface currents in the Rheic Ocean suggest upwelling in this narrow seaway was driven by east-blowing winds and Ekman transport along the southern margin of Avalonia, which formed the northern side of a cyclonic gyre (Figure 11; Pohl et al., 2016; Todd et al., 2019; Pufahl et al., 2020).

The REE + Y composition of ironstone lithofacies (F4, F5, F6, F7) corroborates sedimentologic data suggesting upwelling delivered a sustained supply of anoxic bottom water enriched in hydrothermal Fe to an otherwise oxygenated shelf. Near the upwelling front, where primary production and deposition of sedimentary organic matter were highest (Beckly, 1988 Woodcock, 1990; Brenchley et al., 2006; Howells, 2007), intense bacterial sulfate reduction in the sediment is interpreted to have produced a pyritiferous black shale (F4; Figure 12). Inboard, diminished primary production, advection of ferruginous waters away from the upwelling front, and the cyclic, benthic redox recycling of Fe (Raiswell, 2011) into shallower oxygenated environments are interpreted to have stimulated widespread authigenesis and ironstone accumulation (F5, F6, F7; Petránek, 1991; Todd et al., 2019; Pufahl et al., 2020; Matheson and Pufahl, 2021). The presence of HCS constrains the deposition of ironstone to water depths no deeper than ca. $50 \mathrm{~m}$ (Figure 12; Dumas and Arnott, 2006).

Such an interpretation is consistent with other upwellingrelated ironstones that accumulated along the margins of the Rheic and Iapetus oceans (Petránek, 1991; Todd et al., 2019; Pufahl et al., 2020; Matheson and Pufahl, 2021). What is different about ironstone from the Welsh Basin is the ubiquity of large, coated Fe grains. An upwelled source of Fe contrasts the more traditional view of ironstone deposition that relies on a greenhouse climate and increased chemical weathering for the delivery of continentally derived Fe to the shelf (Van Houten and Bhattacharyya, 1982; Young, 1989, 1992; Van Houten, 2000; Yilmaz et al., 2015).

\section{Coated Fe Grains}

Polymineralic coated grains are the granular equivalent of condensed beds, preserving a high-fidelity record of changing bottom- and pore-water chemistry (Pufahl and Grimm, 2003; Wigley and Compton, 2013; Föllmi, 2016; Diaz and Eberli, 2018). These changes are commonly associated with variations in surface ocean productivity and the export of organic carbon to the seafloor, which, in turn, drives fluctuations in the biological oxygen, pore water $\mathrm{Eh}$, and the precipitation of authigenic minerals forming coated grains (Pufahl and Grimm, 2003). In some environments, bioturbation can periodically flush the sediment with oxygenated seawater to influence pore-water redox potential and authigenesis (Aller, 1982, 1994; Brasier and Callow, 2007). The zone of authigenic precipitation is maintained near the sediment-water interface by intense and prolonged reworking of the seafloor.

Two types of coated grains are the result of the interplay of these processes. Unconformity-bounded grains range in diameter from 200 to $600 \mu \mathrm{m}$ and contain internal erosion surfaces attributed to multiple episodes of reworking, exhumation, and reburial into the zone of authigenic precipitation (Pufahl and Grimm, 2003; Wigley and Compton, 2013). Redox aggraded grains are larger, up to ca. $15 \mathrm{~mm}$ in diameter, and composed of concordant, concentric cortical layers recording minute changes in pore water Eh without wholesale exhumation of grains (Pufahl and Grimm, 2003). Although both grain types occur in the Hen-dy-Capel Ironstone Member (F5, F6, F7), unconformity-bounded grains increase in abundance through Parasequence 1, reflecting aggradation and intensified reworking as the seafloor shallowed to fair weather wave base. Unconformity-bounded grains at the top of Parasequence 1 (F7) are smaller than coated grains near its base (F5; Figure 7) because they are interpreted to have spent less time in the zone of precipitation and there was an abundance of detrital nuclei for cortical layers to form around. Thus, grain type is a sensitive and independent indicator of shelf hydrodynamics through time. With an understanding of cortex mineralogy, oceanographic processes can be related to oxygen gradients in the sediment and across the Welsh Basin.

Redox aggraded grains formed of chamosite and CFA at the base of Parasequence 1 precipitated in sediment (F5) that was accumulating just inboard of the upwelling front. Chamositic cortical laminae record authigenic precipitation in suboxic pores (Glenn and Arthur, 1988; Pufahl and Grimm, 2003). Bioturbation indicates that the irrigation of sediment with oxygenated bottom water was important for maintaining suboxic conditions and focusing the Fe-redox boundary in sediment. Minor productivitydriven changes in pore water Eh are recorded by intercalated CFA cortical layers. Increased deposition and microbial degradation of sedimentary organic matter on the seafloor is interpreted to have 
sufficiently lowered pore water Eh to periodically stop chamosite precipitation and promote the formation of CFA. Although phosphogenesis is a redox independent process, contingent only on the concentration of dissolved phosphate (Glenn and Arthur, 1988; Pufahl, 2010), intensified organic matter degradation is interpreted to have saturated pore water with phosphate. Precipitation of cortical layers was rapid, preserving sponge spicules that usually dissolve quickly in silica-undersaturated pore water (Won and Below, 1999; Kidder and Tomescu, 2016).

Comparison of this high-fidelity record of distal suboxic authigenesis to the redox conditions that formed hematitic unconformity bounded grains in proximal environments (F7) is consistent with an increase in the ichnofabric index that also indicates oxygen levels rose towards the shore. Hematite is interpreted to have formed during diagenesis from an original authigenic $\mathrm{Fe}$-(oxyhydr)oxide precursor. This precursor was likely ferrihydrite $\left(\mathrm{Fe}_{2}^{3+} \mathrm{O}_{3} \cdot 0.5\left(\mathrm{H}_{2} \mathrm{O}\right)\right.$, which reflects precipitation under higher $\mathrm{Eh}$ conditions than chamosite (Taylor and Konhauser, 2011; Taylor and Macquaker, 2011). Cortical layers were produced where ferrous Fe supplied through benthic redox cycling combined with well-oxygenated pore water. Constant wave reworking of the seafloor and intense bioturbation were undoubtedly important for oxygenating pore water.

\section{PALEOZOIC IRONSTONE, OCEAN CHEMISTRY, AND EVOLUTION}

Ventilation of the deep ocean began during the Neoproterozoic Oxygenation Event (800-500 Ma; Och and Shields-Zhou, 2012; Scott \& Lyons, 2012; Shields, 2017), but mounting evidence suggests that a persistently oxygenated deep ocean did not develop until the Permian (Elrick et al., 2011; Kah et al., 2016; Edwards et al., 2017; Lu et al., 2018; Edwards, 2019; Todd et al., 2019; Pufahl et al., 2020; Matheson and Pufahl, 2021). Modelling demonstrates that oxygen concentrations in the oceanatmosphere system were probably lowest in the Middle Ordovician (Edwards et al., 2017). Occurrences of upwellingrelated granular ironstone provide critical insights into this history because they capture nuances of ocean redox structure at the interface between shallow- and deep-water masses. Thus, these occurrences link shelf and abyssal processes to further illuminate the relationship between ocean circulation, seawater chemistry, nutrient availability, and biological evolution.

The ubiquity of upwelling-related ironstone in the Paleozoic suggests that bottom-water anoxia and input of hydrothermal $\mathrm{Fe}$ were common in many restricted seaways (Pufahl et al., 2020; Matheson and Pufahl, 2021). Pronounced episodes of ironstone accumulation in the Ordovician and Devonian (Van Houten and Arthur, 1989; Young, 1992) likely correspond to periods of plate reorganization and increased hydrothermal activity during mantle plume events (Murphy et al., 2009; Yang et al., 2012; Algeo et al., 2016). During these tectonic episodes, the input of volcanogenic $\mathrm{CO}_{2}$ is thought to have acidified the global ocean (Veron, 2008; Kiessling and Simpson, 2011; Torsvik and Cocks, 2017; McKenzie and Jiang, 2019) and greenhouse warming decreased the solubility of $\mathrm{O}_{2}$ in seawater (Veron, 2008; McKenzie and Jiang, 2019).

Ocean acidification is deleterious to calcareous organisms, causing brittle shells and partial dissolution (Kiessling and Simpson, 2011; Hönisch et al., 2012). In contrast, acidic seawater has a neutral to positive effect on the development of siliceous organisms (Webby, 2002; Kidder and Tomescu, 2016). In upwelling-related ironstone, the absence of a diverse assemblage of carbonate-producing organisms and abundance of sponges with siliceous spicules is consistent with this relationship. In the Welsh Basin, sponges, phosphatic brachiopods, and trilobites (Trythall et al., 1987) apparently flourished in waters too acidic to support a healthy carbonate community. The absence of carbonate skeletons in nutrient-rich environments may also reflect a dysoxic seafloor and dissolution associated with the microbial respiration of accumulating organic matter (James et al., 2005). CFA nodules and cortical layers composed of coated $\mathrm{Fe}$ grains record this bacterial process, which also liberates $\mathrm{P}$ from degrading organic matter (Jarvis et al., 1994; Pufahl and Groat, 2017). Sponges thrive under such low Eh and $\mathrm{Ph}$ conditions and therefore can dominate productive middle and distal shelf environments (Mills et al., 2014; Leys and Kahn, 2018; Matheson and Frank, 2020; Chen et al., 2021).

Under a greenhouse climate and diminished capacity for warmer seawater to retain oxygen, anoxic conditions were probably readily established in the narrow, restricted seaways of the Paleozoic. Such anoxia was a pre-requisite for the concentration of hydrothermal Fe and deposition of ironstone in these volcanically active basins. In addition to Fe, upwelling of these ferruginous waters would have delivered a sustained supply of deleterious trace elements to the shelf ( $\mathrm{Cd}, \mathrm{Cu}, \mathrm{As}, \mathrm{Zn}, \mathrm{Co}, \mathrm{Ni}$, Se, Cr, Ba, Ge, As, Pd, Te, and REEs; Wilde et al., 1990), some of which are elevated in the Hen-dy-Capel Ironstone Member. In conjunction with the impingement of anoxic seawater on the shelf, the availability of these toxic trace elements is interpreted to have triggered regional extinctions that punctuate major biological diversification events such as the GOBE (Vandenbroucke et al., 2015; Pufahl et al., 2020; Matheson and Pufahl, 2021). The accumulation of upwelling-related ironstone in periods of post-extinction recovery suggests that over time ironstone accumulation was also an important sink that lowered the metal toxicity of seawater (Pufahl et al., 2020). The cyclic changes in pore water redox potential required to sequester these trace elements through repeated episodes of scavenging and absorption at the seafloor are preserved in the cortical mineralogy of coated Fe grains. This "kill and cure" mechanism (Pufahl et al., 2020) is interpreted to have contributed to pulses of graptolite diversification in the Welsh Basin (Kokelaar et al., 1985; Brenchley et al., 2006; Howells, 2007) by providing upwelling derived nutrients (Young et al., 2002; Pohl et al., 2016) and lowering metal toxicity (Matheson and Pufahl, 2021). This negative feedback process is thought to have contributed to other post-extinction faunal recoveries that assisted with increasing marine biodiversity through the GOBE (Pufahl et al., 2020). A similar feedback may have also been important in the Devonian when biological turnover was also linked to environmental volatility and periods of shelf anoxia 
(Bond and Wignall, 2008; Brett et al., 2020). Application of this upwelling model to even younger ironstones and contemporaneous trace element enriched black shales may also provide important new constraints regarding the redox structure and oxygenation history of the Mesozoic oceans.

\section{CONCLUSION}

1) Ironstone of the Hen-dy-Capel Ironstone Member of the Tygarn Formation, Ogwen Group, constitutes a single shallowing upward parasequence (Parasequence 1) recording stratigraphic condensation during maximum transgression. Overlying terrigenous clastic facies form a second parasequence (Parasequence 2) interpreted to record the onset of progradation during highstand conditions.

2) Lithofacies associations in Parasequence 1 are consistent with ironstone accumulation on a storm-dominated shelf with active coastal upwelling. Conspicuous coated $\mathrm{Fe}$ grains augment this understanding by linking shelf and abyssal processes to capture nuances in ocean chemistry and seawater redox structure.

3) For the first time, the REE $+\mathrm{Y}$ and the trace metal composition of Phanerozoic ironstone is used to corroborate sedimentologic data suggesting upwelling delivered a sustained supply of anoxic bottom water enriched in hydrothermal $\mathrm{Fe}$ to an otherwise oxygenated shelf. Such an interpretation is consistent with other upwelling-related ironstones that accumulated along the margins of the Rheic and Iapetus oceans. This style of Fe delivery harks back to the Precambrian when upwelling produced giant continental margin iron formations.

4) In addition to Fe, upwelling of this hydrothermally enriched seawater would have delivered a sustained supply of toxic trace elements to the shelf, triggering regional extinctions that punctuate major biological diversification events such as the GOBE. The accumulation of upwelling-related ironstone

\section{REFERENCES}

Ackerman, L., HajnáZák, J. J., Žák, J., Erban, V., Sláma, J., Polák, L., et al. (2019). Architecture and Composition of Ocean Floor Subducted beneath Northern Gondwana during Neoproterozoic to Cambrian: a Palinspastic Reconstruction Based on Ocean Plate Stratigraphy (OPS). Gondwana Res. 76, 77-97. doi:10.1016/j.gr.2019.07.001

Algeo, T. J., Marenco, P. J., and Saltzman, M. R. (2016). Co-evolution of Oceans, Climate, and the Biosphere during the 'Ordovician Revolution': A Review. Palaeogeogr. Palaeoclimatol. Palaeoecol. 458, 1-11. doi:10.1016/ j.palaeo.2016.05.015

Aller, R. C. (1994). Bioturbation and Remineralization of Sedimentary Organic Matter: Effects of Redox Oscillation. Chem. Geology. 114, 331-345. doi:10.1016/ 0009-2541(94)90062-0

Aller, R. C. (1982). "The Effects of Macrobenthos on Chemical Properties of marine Sediment and Overlying Water," in In Animal-Sediment Relations Topics in Geobiology 100. Editors P.L. McCall and M.J.S. Tevesz (Boston: Springer), 53-102. doi:10.1007/978-1-4757-1317-6_2 during periods of post-extinction recovery suggests that with time the accumulation of ironstone titrated these metals and lowered seawater toxicity. This "kill and cure" mechanism is a chemical-ecological feedback process that may have contributed to biological turnover until the deep ocean became fully oxygenated in the late Paleozoic.

\section{DATA AVAILABILITY STATEMENT}

The original contributions presented in the study are included in the article, further inquiries can be directed to the corresponding author.

\section{AUTHOR CONTRIBUTIONS}

The manuscript is based on the MSc thesis research of SD. As SD's supervisor, PP assisted in the field, data collection, data interpretation, and manuscript preparation. JM and $\mathrm{BM}$ also assisted in the field, broad-scale conceptual ideas critical to the science, and manuscript review.

\section{FUNDING}

Natural Sciences and Engineering Research Council of Canada (NSERC) Discovery Grants to PP and BM. Acadia Graduate Awards and a NSERC Canada Graduate Scholarship to SD.

\section{ACKNOWLEDGMENTS}

Reviews by Guest Editor Riedinger and three reviewers improved this manuscript. P. Frail prepared polished thin sections. C. Koebernick reviewed previous iterations of the text. J. Malone assisted with fieldwork. AGAT Laboratories are gratefully acknowledged for geochemical analyses.

Anthony, J. W., Bideaux, R. A., Bladh, K. W., and Nichols, M. C. (2001). “Silica, Silicates," in Handbook of Mineralogy. Editors J.W. Anthony, R.A. Bideaux, K.W. Bladh, and M.C. Nichols (Chantilly, VA, USA): Mineralogical Society of America), 458.

Arning, E. T., Birgel, D., Brunner, B., and Peckmann, J. (2009). Bacterial Formation of Phosphatic Laminites off Peru. Geobiology 7, 295-307. doi:10.1111/j.14724669.2009.00197.x

Bau, M., and Dulski, P. (1999). Comparing Yttrium and Rare Earths in Hydrothermal Fluids from the Mid-Atlantic Ridge: Implications for Y and REE Behaviour during Near-Vent Mixing and for the Y/Ho Ratio of Proterozoic Seawater. Chem. Geology. 155, 77-90. doi:10.1016/S00092541(98)00142-9

Bau, M., and Dulski, P. (1994). Evolution of the Yttrium-Holmium Systematics of Seawater through Time. Mineralogical Mag. 58A, 61-62. doi:10.1180/ minmag.1994.58A.1.35

Bau, M., Koschinsky, A., Dulski, P., and Hein, J. R. (1996). Comparison of the Partitioning Behaviours of Yttrium, Rare Earth Elements, and Titanium between Hydrogenetic marine Ferromanganese Crusts and Seawater. Geochimica et Cosmochimica Acta 60, 1709-1725. doi:10.1016/00167037(96)00063-4 
Bau, M. (1991). Rare-earth Element Mobility during Hydrothermal and Metamorphic Fluid-Rock Interaction and the Significance of the Oxidation State of Europium. Chem. Geology. 93, 219-230. doi:10.1016/0009-2541(91)90115-8

Bau, M., Schmidt, K., Koschinsky, A., Hein, J., Kuhn, T., and Usui, A. (2014). Discriminating between Different Genetic Types of marine Ferro-Manganese Crusts and Nodules Based on Rare Earth Elements and Yttrium. Chem. Geology. 381, 1-9. doi:10.1016/j.chemgeo.2014.05.004

Bayon, G., Toucanne, S., Skonieczny, C., André, L., Bermell, S., Cheron, S., et al. (2015). Rare Earth Elements and Neodymium Isotopes in World River Sediments Revisited. Geochimica et Cosmochimica Acta 170, 17-38. doi:10.1016/j.gca.2015.08.001

Beckly, A. J. (1988). The Stratigraphy of the Arenig Series in the Aberdaron to Sarn Area, Western Llŷcn, North Wales. Geol. J. 23, 321-337. doi:10.1002/ gj.3350230404

Behl, R., and Garrison, R. E. (1994). The Origin of Chert in the Monterey Formation of California (USA). Proc. 29th Int. Geol. Congress, 101-132.

Bekker, A., Slack, J. F., Planavsky, N., Krapež, B., Hofmann, A., Konhauser, K. O., et al. (2010). Iron Formation: The Sedimentary Product of a Complex Interplay Among Mantle, Tectonic, Oceanic, and Biospheric Processes. Econ. Geology. 105, 467-508. doi:10.2113/gsecongeo.105.3.467

Bond, D. P. G., and Wignall, P. B. (2008). The Role of Sea-Level Change and marine Anoxia in the Frasnian-Famennian (Late Devonian) Mass Extinction. Palaeogeogr. Palaeoclimatol. Palaeoecol. 263, 107-118. doi:10.1016/j.palaeo.2008.02.015

Botting, J. P., and Muir, L. A. (2013). Spicule Structure and Affinities of the Late Ordovician Hexactinellid-like Sponge Cyathophycus Loydelli from the Llanfawr Mudstones Lagerstätte, Wales. Lethaia 46, 454-469. doi:10.1111/ let. 12022

Boyd, R. (2010). "Trangressive Wave-Dominated Coasts," in In Facies Models 4. Editors N. P. James and R. W. Dalrymple (St. John's, Canada: Geological Association of Canada)), 265-294.

Brasier, M. D., and Callow, R. H. T. (2007). Changes in the Patterns of Phosphatic Preservation across the Proterozoic-Cambrian Transition. Mem. Assoc. Australas. Palaeontologists 34, 377-389.

Brenchley, P. J., Rushton, A. W. A., Howells, M. F., and Cave, R. (2006). “Cambrian and Ordovician: the Early Palaeozoic Tectonostratigraphic Evolution of the Welsh Basin, Midland and Monian Terranes of Eastern Avalonia," in The Geology of England and Wales. Editors P. J. Brenchley and P. F. Rawson (Bath, UK: Geological Society of London), 25-74.

Brett, C. E., Zambito, J. J., McLaughlin, P. I., and Emsbo, P. (2020). Revised Perspectives on Devonian Biozonation and Environmental Volatility in the Wake of Recent Time-Scale Revisions. Palaeogeogr. Palaeoclimatol. Palaeoecol. 549, 108843-108910. doi:10.1016/j.palaeo.2018.06.037

Brown, M. J., and Evans, A. D. (1989). 89/14. Keyworth, UK: British Geological Survey Technical Report WF/, 84.Geophysical and Geochemical Investigations of the Manganese Deposits of Rhiw, Western Llyn, North Wales

Canfield, D. E., and Thamdrup, B. (2009). Towards a Consistent Classification Scheme for Geochemical Environments, or, Why We Wish the Term 'suboxic' Would Go Away. Geobiology 7, 385-392. doi:10.1111/j.14724669.2009.00214.x

Casas, J. M., and Brendan Murphy, J. (2018). Unfolding the Arc: the Use of Preorogenic Constraints to Assess the Evolution of the Variscan belt in Western Europe. Tectonophysics 736, 47-61. doi:10.1016/j.tecto.2018.04.012

Catuneanu, O., Galloway, W. E., Kendall, C. G. S. t. C., Miall, A. D., Posamentier, H. W., Strasser, A., et al. (2011). Sequence Stratigraphy: Methodology and Nomenclature. nos 44, 173-245. doi:10.1127/0078-0421/2011/0011

Catuneanu, O. (2019). Scale in Sequence Stratigraphy. Mar. Pet. Geology. 106, 128-159. doi:10.1016/j.marpetgeo.2019.04.026

Challands, T. J., Armstrong, H. A., Maloney, D. P., Davies, J. R., Wilson, D., and Owen, A. W. (2009). Organic-carbon Deposition and Coastal Upwelling at Mid-latitude during the Upper Ordovician (Late Katian): A Case Study from the Welsh Basin, UK. Palaeogeogr. Palaeoclimatol. Palaeoecol. 273, 395-410. doi:10.1016/j.palaeo.2008.10.004

Chen, F., Pufahl, P. K., Wang, Q., Matheson, E. J., Shabaga, B. M., Zhang, Q., et al. (2021). A New Model for the Genesis of Carboniferous Mn Ores, Longtou deposit, South China Block. Econ. Geology. doi:10.5382/econgeo.4855

Cocks, L. R. M., and Torsvik, T. H. (2002). Earth Geography from 500 to 400 Million Years Ago: a Faunal and Palaeomagnetic Review. J. Geol. Soc. 159, 631-644. doi:10.1144/0016-764901-118
Cohen, K. M., Finney, S. C., Gibbard, P. L., and Fan, J. (2019). The ICS International Chronostratigraphic Chart. Episodes 36, 199-204. doi:10.18814/epiiugs/2013/v36i3/002

Condie, K. C. (1993). Chemical Composition and Evolution of the Upper continental Crust: Contrasting Results from Surface Samples and Shales. Chem. Geology. 104, 1-37. doi:10.1016/0009-2541(93)90140-E

Cooper, R. A., Sadler, P. M., Hammer, O., and Gradstein, F. M. (2012). "The Ordovician Period," in "Chapter 20 - the Ordovician Period," in the Geologic Time Scale. Editors F. M. Gradstein, J. G. Ogg, M. D. Schmitz, and G. M. Ogg (Boston: Elsevier), 489-523. doi:10.1016/B978-0-444-59425-9.00020-2

Danielson, A., Möller, P., and Dulski, P. (1992). The Europium Anomalies in Banded Iron Formations and the thermal History of the Oceanic Crust. Chem. Geology. 97, 89-100. doi:10.1016/0009-2541(92)90137-T

Derry, L. A., and Jacobsen, S. B. (1990). The Chemical Evolution of Precambrian Seawater: Evidence from REEs in Banded Iron Formations. Geochimica et Cosmochimica Acta 54, 2965-2977. doi:10.1016/0016-7037(90)90114-Z

Diaz, M. R., and Eberli, G. P. (2019). Decoding the Mechanism of Formation in marine Ooids: A Review. Earth-Science Rev. 190, 536-556. doi:10.1016/ j.earscirev.2018.12.016

Dott, R. H., and Bourgeois, J. (1982). Hummocky Stratification: Significance of its Variable Bedding Sequences. Geol. Soc. America Bull. 93, 663-680. doi:10.1130/ 0016-7606(1982) $93<663$ :HSSOIV >2.0.CO;2

Droser, M. L., and Bottjer, D. J. (1986). A Semiquantitative Field Classification of Ichnofabric. J. Sediment. Res. 56, 558-559. doi:10.1306/212F89C2-2B24-11D78648000102C1865D

Dubinin, A. V. (2004). Geochemistry of Rare Earth Elements in the Ocean. Lithology Mineral. Resour. 39, 289-307. doi:10.1023/b: limi.0000033816.14825.a2

Dumas, S., and Arnott, R. W. C. (2006). Origin of Hummocky and Swaley CrossStratification- the Controlling Influence of Unidirectional Current Strength and Aggradation Rate. Geol 34, 1073. doi:10.1130/G22930A.1

Dunham, R. J. (1962). "Classification of Carbonate Rocks According to Depositional Texture," in In Classification of Carbonate Rocks. Editor W.E. Ham (Tulsa, OK: AAPG)), 108-121.

Edwards, C. T. (2019). Links between Early Paleozoic Oxygenation and the Great Ordovician Biodiversification Event (GOBE): A Review. Palaeoworld 28, 37-50. doi:10.1016/j.palwor.2018.08.006

Edwards, C. T., Saltzman, M. R., Royer, D. L. D., and Fike, D. A. D. (2017). Oxygenation as a Driver of the Great Ordovician Biodiversification Event. Nat. Geosci 10, 925-929. doi:10.1038/s41561-017-0006-3

Elderfield, H., and Greaves, M. J. (1982). The Rare Earth Elements in Seawater. Nature 296, 214-219. doi:10.1038/296214a0

Elrick, M., Rieboldt, S., Saltzman, M., and McKay, R. M. (2011). Oxygen-isotope Trends and Seawater Temperature Changes across the Late Cambrian Steptoean Positive Carbon-Isotope Excursion (SPICE Event). Geology 39, 987-990. doi:10.1130/g32109.1

Filippelli, G. M. (2008). The Global Phosphorus Cycle: Past, Present, and Future. Elements 4, 89-95. doi:10.2113/gselements.4.2.89

Folk, R. L. (1980). Petrology of Sedimentary Rocks. Austin: Hemphill Publishing), 184. p.

Föllmi, K. B. (2016). Sedimentary Condensation. Earth-Science Rev. 152, 143-180. doi:10.1016/j.earscirev.2015.11.016

Föllmi, K. (1996). The Phosphorus Cycle, Phosphogenesis and marine PhosphateRich Deposits. Earth-Science Rev. 40, 55-124. doi:10.1016/0012-8252(95) 00049-6

Fortey, R. A., and Cocks, L. R. M. (2003). Palaeontological Evidence Bearing on Global Ordovician-Silurian continental Reconstructions. Earth-Science Rev. 61, 245-307. doi:10.1016/S0012-8252(02)00115-0

Froelich, P. N., Klinkhammer, G. P., Bender, M. L., Luedtke, N. A., Heath, G. R., Cullen, D., et al. (1979). Early Oxidation of Organic Matter in Pelagic Sediments of the Eastern Equatorial Atlantic: Suboxic Diagenesis. Geochimica et Cosmochimica Acta 43, 1075-1090. doi:10.1016/0016-7037(79)90095-4

García-Arias, M., Díez-Montes, A., Villaseca, C., and Blanco-Quintero, I. F. (2018). The Cambro-Ordovician Ollo de Sapo magmatism in the Iberian Massif and its Variscan evolution: A review. Earth-Science Rev. 176, 345-372. doi:10.1016/ j.earscirev.2017.11.004

Ghadeer, S. G., and Macquaker, J. H. S. (2011). 168. London, 1121-1132. doi:10.1144/0016-76492010-016Sediment Transport Processes in an Ancient 
Mud-Dominated Succession: a Comparison of Processes Operating in marine Offshore Settings and Anoxic Basinal EnvironmentsJ. Geol. Soc.

Glenn, C., Föllmi, K., Riggs, S., Baturin, G., Grimm, K., Trappe, J., et al. (1994). Phosphorus and Phosphorites: Sedimentology and Environments of Formation. Eclogae Geologicae Helvetica 87, 747-788.

Glenn, C. R., and Arthur, M. A. (1988). Petrology and Major Element Geochemistry of Peru Margin Phosphorites and Associated Diagenetic Minerals: Authigenesis in Modern Organic-Rich Sediments. Mar. Geology. 80, 231-267. doi:10.1016/0025-3227(88)90092-8

Greenough, J. D., and Papezik, V. S. (). Petrology and Geochemistry of Cambrian Volcanic Rocks from the Avalon Peninsula, Newfoundland. Can. J. Earth Sci. 22, 1594-160l. doi:10.1139/e85-168

Gromet, L. P., Haskin, L. A., Korotev, R. L., and Dymek, R. F. (1984). The "North American Shale Composite": Its Compilation, Major and Trace Element Characteristics. Geochimica et Cosmochimica Acta 48, 2469-2482. doi:10.1016/0016-7037(84)90298-9

Gross, G. A. (1983). Tectonic Systems and the Deposition of Iron-Formation. Precambrian Res. 20, 171-187. doi:10.1016/0301-9268(83)90072-4

Gutiérrez-Alonso, G., Gutiérrez-Marco, J. C., Fernández-Suárez, J., Bernárdez, E., and Corfu, F. (2016). Was There a Super-eruption on the Gondwanan Coast 477 Ma Ago? Tectonophysics 681, 85-94. doi:10.1016/j.tecto.2015.12.012

Haley, B. A., Klinkhammer, G. P., and McManus, J. (2004). Rare Earth Elements in Pore Waters of marine Sediments. Geochimica et Cosmochimica Acta 68, 1265-1279. doi:10.1016/j.gca.2003.09.012

Harder, H. (1980). Syntheses of Glauconite at Surface Temperatures. Clays and Clay Minerals 28, 217-222. doi:10.1346/ccmn.1980.0280308

Heggie, D. T., Skyring, G. W., O’Brien, G. W., Reimers, C., Herczeg, A., Moriarty, D. J. W., et al. (1990). Organic Carbon Cycling and Modern Phosphorite Formation on the East Australian continental Margin: an Overview. Geol. Soc. Lond. Spec. Publications 52, 87-117. doi:10.1144/gsl.sp.1990.052.01.07

Henderson, B. J., Collins, W. J., Murphy, J. B., Gutierrez-Alonso, G., and Hand, M. (2016). Gondwanan Basement Terranes of the Variscan-Appalachian Orogen: Baltican, Saharan and West African Hafnium Isotopic Fingerprints in Avalonia, Iberia and the Armorican Terranes. Tectonophysics 681, 278-304. doi:10.1016/ j.tecto.2015.11.020

Hiatt, E. E., Pufahl, P. K., and Edwards, C. T. (2015). Sedimentary Phosphate and Associated Fossil Bacteria in a Paleoproterozoic Tidal Flat in the $1.85 \mathrm{Ga}$ Michigamme Formation, Michigan, USA. Sediment. Geology. 319, 24-39. doi:10.1016/j.sedgeo.2015.01.006

Hönisch, B., Ridgwell, A., Schmidt, D. N., Thomas, E., Gibbs, S. J., Sluijs, A., et al. (2012). The Geological Record of Ocean Acidification. Science 335, 1058-1063. doi:10.1126/science.1208277

Howells, M. F. (2007). “Ordovician," in British Regional Geology: Wales. Editor M. F. Howells (Keyworth, Nottingham: British Geological Survey)), 36-71.

Howells, M. F., and Smith, M. (1997). Geology of the Country Around Snowdon. London: Memoir of the British Geological Survey, Sheet 119 (England and Wales).

Jahnke, R. A., Emerson, S. R., Roe, K. K., and Burnett, W. C. (1983). The Present Day Formation of Apatite in Mexican continental Margin Sediments. Geochimica et Cosmochimica Acta 47, 259-266. doi:10.1016/0016-7037(83)90138-2

James, N. P., Bone, Y., and Kyser, T. K. (2005). Where Has All the Aragonite Gone? Mineralogy of Holocene Neritic Cool-Water Carbonates, Southern Australia. J. Sediment. Res. 75, 454-463. doi:10.2110/jsr.2005.035

James, N. P., and Jones, B. (2016). "The Time Machine," in Origin of Carbonate Sedimentary Rocks. Editors N. P. James and B. Jones (West Sussex, United Kingdom: John Wiley \& Sons), 261-272.

Janoušek, V., Moyen, J.-F., Martin, H., Erban, V., and Farrow, C. (2016). Geochemical Modelling of Igneous Processes - Principles and Recipes in $R$ Language: Bringing the Power of $R$ to a Geochemical Community. Berlin Heidelberg: Springer-Verlag.

Jarvis, I., Burnett, W. C., Nathan, Y., Almbaydin, F. S. M., Attia, A. K. M., and Castrol, L. N. (1994). Phosphorite Geochemistry: State of the Art and Environmental Concerns. Eclogae Geol. Helv. 87, 643-700.

Kah, L. C., Thompson, C. K., Henderson, M. A., and Zhan, R. (2016). Behavior of marine Sulfur in the Ordovician. Palaeogeogr. Palaeoclimatol. Palaeoecol. 458, 133-153. doi:10.1016/j.palaeo.2015.12.028

Kidder, D. L., and Tomescu, I. (2016). Biogenic Chert and the Ordovician Silica Cycle. Palaeogeogr. Palaeoclimatol. Palaeoecol. 458, 29-38. doi:10.1016/ j.palaeo.2015.10.013
Kiessling, W., and Simpson, C. (2011). On the Potential for Ocean Acidification to Be a General Cause of Ancient Reef Crises. Glob. Change Biol. 17, 56-67. doi:10.1111/j.1365-2486.2010.02204.x

Klein, C. (2005). Some Precambrian Banded Iron-Formations (BIFs) from Around the World: Their Age, Geologic Setting, Mineralogy, Metamorphism, Geochemistry, and Origins. Am. Mineral. 90, 1473-1499. doi:10.2138/ am.2005.1871

Kokelaar, B. P., Bevins, R. E., and Roach, R. A. (1985). Submarine Silicic Volcanism and Associated Sedimentary and Tectonic Processes, Ramsey Island, SW Wales. J. Geol. Soc. 142, 591-613. doi:10.1144/gsjgs.142.4.0591

Kokelaar, B. P., Howells, M. F., Bevins, R. E., Roach, R. A., and Dunkley, P. N. (1984). The Ordovician Marginal basin of Wales. Geol. Soc. Lond. Spec. Publications 16, 245-269. doi:10.1144/GSL.SP.1984.016.01.19

Leys, S. P., and Kahn, A. S. (2018). Oxygen and the Energetic Requirements of the First Multicellular Animals. Integr. Comp. Biol. 58, 666-676. doi:10.1093/icb/ icy051

Linnemann, U., Herbosch, A., Liégeois, J.-P., Pin, C., Gärtner, A., and Hofmann, M. (2012). The Cambrian to Devonian Odyssey of the Brabant Massif within Avalonia: A Review with New Zircon Ages, Geochemistry, Sm-Nd Isotopes, Stratigraphy and Palaeogeography. Earth-Science Rev. 112, 126-154. doi:10.1016/j.earscirev.2012.02.007

Lu, W., Ridgwell, A., Thomas, E., Hardisty, D. S., Luo, G., Algeo, T. J., et al. (2018). Late Inception of a Resiliently Oxygenated Upper Ocean. Science 361, 174-177. doi:10.1126/science.aar5372

Matheson, E. J., and Frank, T. D. (2020). Phosphorites, Glass Ramps and Carbonate Factories: the Evolution of an Epicontinental Sea and a Late Palaeozoic Upwelling System (Phosphoria Rock Complex). Sedimentology. doi:10.1111/ sed.12731

Matheson, E. J., and Pufahl, P. K. (2021). Clinton Ironstone Revisited and Implications for Silurian Earth System Evolution. Earth-Science Rev. 215, 103527-103535. doi:10.1016/j.earscirev.2021.103527

McKenzie, N. R., and Jiang, H. (2019). Earth's Outgassing and Climatic Transitions: The Slow Burn towards Environmental "Catastrophes"? Elements 15, 325-330. doi:10.2138/gselements.15.5.325

McLennan, S. M. (1989). Chapter 7. RARE EARTH ELEMENTS IN SEDIMENTARY ROCKS: INFLUENCE of PROVENANCE and SEDIMENTARY PROCESSES. Rev. Mineralogy 21, 169-200. doi:10.1515/ 9781501509032-010

Montero, P., Talavera, C., Bea, F., Lodeiro, F. G., and Whitehouse, M. J. (2009). Zircon Geochronology of the Ollo de Sapo Formation and the Age of the Cambro-Ordovician Rifting in Iberia. J. Geology. 117, 174-191. doi:10.1086/ 595017

Morgan, J. W., Higuchi, H., Takahashi, H., and Hertogen, J. (1978). A "Chondritic" Eucrite Parent Body: Inference from Trace Elements. Geochimica et Cosmochimica Acta 42, 27-38. doi:10.1016/0016-7037(78)90213-2

Mulhern, J. S., Johnson, C. L., and Martin, J. M. (2019). Modern to Ancient Barrier Island Dimensional Comparisons: Implications for Analog Selection and Paleomorphodynamics. Front. Earth Sci. 7. doi:10.3389/ feart.2019.00109

Murphy, J. B., Cameron, K., Dostal, J., Keppie, J. D., and Hynes, A. J. (1985). Cambrian Volcanism in Nova Scotia, Canada. Can. J. Earth Sci. 22, 599-606. doi:10.1139/e85-059

Murphy, J. B., Dostal, J., and Keppie, J. D. (2008). Neoproterozoic-Early Devonian Magmatism in the Antigonish Highlands, Avalon Terrane, Nova Scotia: Tracking the Evolution of the Mantle and Crustal Sources during the Evolution of the Rheic Ocean. Tectonophysics 461, 181-201. doi:10.1016/ j.tecto.2008.02.003

Murphy, J. B., Fernández-Suárez, J., and Jeffries, T. E. (2004). Lithogeochemical and $\mathrm{Sm}-\mathrm{Nd}$ and U-Pb Isotope Data from the Silurian-Lower Devonian Arisaig Group Clastic Rocks, Avalon Terrane, Nova Scotia: A Record of Terrane Accretion in the Appalachian-Caledonide Orogen. Geol. Soc. America Bull. 116, 1183-1201. doi:10.1130/B25423.1

Murphy, J. B., Nance, R. D., Cawood, P. A., Collins, W. J., Dan, W., Doucet, L., et al. (2021). "Pannotia: In Defence of its Existence and Geodynamic Significance," in Pannotia to Pangea: Neoproterozoic and Paleozoic Orogenic Cycles in the Circum-North Atlantic Region. Editors J. B. Murphy, R. A. Strachan, and C. Quesada (Bath, UK: Geological Society, London, Special Publication), 503, 13-39. doi:10.1144/sp503 
Murphy, J. B., Nance, R. D., and Cawood, P. A. (2009). Contrasting Modes of Supercontinent Formation and the Conundrum of Pangea. Gondwana Res. 15, 408-420. doi:10.1016/j.gr.2008.09.005

Nance, R. D., Gutiérrez-Alonso, G., Keppie, J. D., Linnemann, U., Murphy, J. B., Quesada, C., et al. (2010). Evolution of the Rheic Ocean. Gondwana Res. 17, 194-222. doi:10.1016/j.gr.2009.08.001

Nesse, W. (2015). "Silicates," in Introduction to Mineralogy. Oxford, United Kingdom: Oxford University Press, 183-200.

Och, L. M., and Shields-Zhou, G. A. (2012). The Neoproterozoic Oxygenation Event: Environmental Perturbations and Biogeochemical Cycling. EarthScience Rev. 110, 26-57. doi:10.1016/j.earscirev.2011.09.004

Ohta, A., and Kawabe, I. (2001). REE(III) Adsorption onto Mn Dioxide ( $\delta$-MnO2) and Fe Oxyhydroxide: Ce(III) Oxidation by $\delta$-MnO2. Geochimica et Cosmochimica Acta 65, 695-703. doi:10.1016/S0016-7037(00)00578-0

Olivarez, A. M., and Owen, R. M. (1991). The Europium Anomaly of Seawater: Implications for Fluvial versus Hydrothermal REE Inputs to the Oceans. Chem. Geology. 92, 317-328. doi:10.1016/0009-2541(91)90076-4

Parrish, J. T. (1982). Upwelling and Petroleum Source Beds, with Reference to Paleozoic. Am. Assoc. Pet. Geol. Bull 66, 750-774. doi:10.1306/03B5A30E16D1-11D7-8645000102C1865D

Petránek, J. (1991). Ordovician Oolitic Ironstones and Their Source of Iron. Věst. Ústř. Úst. geol.(Praha) 66, 321-327.

Piper, D. Z., Baedecker, P. A., Crock, J. G., Burnett, W. C., and Loebner, B. J. (1988). Rare Earth Elements in the Phosphatic-Enriched Sediment of the Peru Shelf. Mar. Geology. 80, 269-285. doi:10.1016/0025-3227(88)90093-x

Piper, D. Z., and Calvert, S. E. (2009). A marine Biogeochemical Perspective on Black Shale Deposition. Earth-Science Rev. 95, 63-96. doi:10.1016/ j.earscirev.2009.03.001

Planavsky, N., Bekker, A., Rouxel, O. J., Kamber, B., Hofmann, A., Knudsen, A., et al. (2010). Rare Earth Element and Yttrium Compositions of Archean and Paleoproterozoic Fe Formations Revisited: New Perspectives on the Significance and Mechanisms of Deposition. Geochimica et Cosmochimica Acta 74, 6387-6405. doi:10.1016/j.gca.2010.07.021

Plint, A. G. (2010). "Wave- and Storm-Dominated Shallow marine Systems," in In Facies Models 4. Editors N. P. James and R. W. Dalrymple (St. John's, Canada: Geological Association of Canada)), 167-199.

Pohl, A., Nardin, E., Vandenbroucke, T. R. A., and Donnadieu, Y. (2016). High Dependence of Ordovician Ocean Surface Circulation on Atmospheric CO2 Levels. Palaeogeogr. Palaeoclimatol. Palaeoecol. 458, 39-51. doi:10.1016/ j.palaeo.2015.09.036

Pothier, H. D., Waldron, J. W. F., Schofield, D. I., and DuFrane, S. A. (2015). PeriGondwanan Terrane Interactions Recorded in the Cambrian-Ordovician Detrital Zircon Geochronology of North Wales. Gondwana Res. 28, 987-1001. doi:10.1016/j.gr.2014.08.009

Prigmore, J. K., Butler, A. J., and Woodcock, N. H. (1997). Rifting during Separation of Eastern Avalonia from Gondwana: Evidence from Subsidence Analysis. Geol 25, 203-206. doi:10.1130/0091-7613(1997)025<0203: rdsoea $>2.3 . \mathrm{co} ; 2$

Pufahl, P. K. (2010). in "Bioelemental Sediments," in Facies Models 4. Editors N. P. James and R. W. Dalrymple (St. John's, Canada: Geological Association of Canada)), 477-504.

Pufahl, P. K., and Grimm, K. A. (2003). Coated Phosphate Grains: Proxy for Physical, Chemical, and Ecological Changes in Seawater. Geol 31, 801-804. doi:10.1130/G19658.1

Pufahl, P. K., and Groat, L. A. (2017). Sedimentary and Igneous Phosphate Deposits: Formation and Exploration: An Invited Paper. Econ. Geology. 112, 483-516. doi:10.2113/econgeo.112.3.483

Pufahl, P. K., Squires, A. D., Murphy, J. B., Quesada, C., Lokier, S. W., Álvaro, J. J., et al. (2020). Ordovician Ironstone of the Iberian Margin: Coastal Upwelling, Ocean Anoxia and Palaeozoic Biodiversity. Depositional Rec. 6, 581-604. doi:10.1002/dep2.113

Quin, J. G. (2011). Is Most Hummocky Cross-Stratification Formed by Large-Scale Ripples? Sedimentology 58, 1414-1433. doi:10.1111/j.1365-3091.2010.01219.x

Raiswell, R., and Canfield, D. E. (2012). The Iron Biogeochemical Cycle Past and Present. GeochemPersp 1, 1-220. doi:10.7185/geochempersp.1.1

Raiswell, R. (2011). Iron Transport from the Continents to the Open Ocean: The Aging-Rejuvenation Cycle. Elements 7, 101-106. doi:10.2113/ gselements.7.2.101
Rushton, A. W. A., and Fortey, R. A. (2000). "North Wales," in A Revised Correlation Ordovician Rocks. R. A. Fortey, D. A. T. Harper, J. K. Ingham, A. W. Owen, M. A. Parkes, A. W. A. Rushton, et al. (Bath, UK: Geological Society of London), 18-24. doi:10.1144/SR24.5

Rushton, A. W. A., and Howells, M. F. (1998). Stratigraphical Framework for the Ordovician of Snowdonia and the Lleyn Peninsula: A Discussion of the Tremadoc to Caradoc Rocks Lying between the Menai Straits and the Llanderfel Syncline, and Including an Appendix on Cambrian Rocks. Keyworth: British Geological Survey). Report No. RR/98/001.

Sánchez-García, T., Bellido, F., and Quesada, C. (2003). Geodynamic Setting and Geochemical Signatures of Cambrian-Ordovician Rift-Related Igneous Rocks (Ossa-Morena Zone, SW, Iberia). Tectonophysics 365, 233-255. doi:10.1016/ s0040-1951(03)00024-6

Sánchez-García, T., Quesada, C., Bellido, F., Dunning, G. R., and González del Tánago, J. (2008). Two-step Magma Flooding of the Upper Crust during Rifting: The Early Paleozoic of the Ossa Morena Zone (SW Iberia). Tectonophysics 461, 72-90. doi:10.1016/j.tecto.2008.03.006

Schieber, J. (2002). Sedimentary Pyrite: A Window into the Microbial Past. Geology, 30, 2. doi:10.1130/0091-7613(2002)030<0531:spawit>2.0.co;2

Schieber, J. (2003). Simple Gifts and Buried Treasures-Implications of Finding Bioturbation and Erosion Surfaces in Black Shales. Sed Rec. 1, 4-8. doi:10.2110/ sedred.2003.2.4

Scott, C., and Lyons, T. W. (2012). Contrasting Molybdenum Cycling and Isotopic Properties in Euxinic versus Non-euxinic Sediments and Sedimentary Rocks: Refining the Paleoproxies. Chem. Geology. 324-325 (325), 19-27. doi:10.1016/ j.chemgeo.2012.05.012

Servais, T., Harper, D. A. T., Munnecke, A., Owen, A. W., and Sheehan, P. M. (2009). Understanding the Great Ordovician Biodiversification Event (GOBE): Influences of Paleogeography, Paleoclimate, or Paleoecology. GSA Today 19, 4-10. doi:10.1130/gsatg37a.1

Servais, T., Owen, A. W., Harper, D. A. T., Kröger, B., and Munnecke, A. (2010). The Great Ordovician Biodiversification Event (GOBE): The Palaeoecological Dimension. Palaeogeogr. Palaeoclimatol. Palaeoecol. 294, 99-119. doi:10.1016/ j.palaeo.2010.05.031

Shanmugam, G., Spalding, T. D., and Rofheart, D. H. (1993). Traction Structures in deep-marine, Bottom-Current-Reworked Sands in the Pliocene and Pleistocene, Gulf of Mexico. Geology 21, 929-932. doi:10.1130/00917613(1993)021<0929:TSIDMB > 2.3.CO;2

Shields, G. A. (2017). "Earth System Transition during the Tonian-Cambrian Interval of Biological Innovation: Nutrients, Climate, Oxygen and the marine Organic Carbon Capacitor," in In Earth System Evolution and Early Life: A Celebration of the Work of Martin Brasier. Editors A. T. Brasier, D. McIlroy, and N. McLoughlin (London): Geological Society), 448, 161-177. doi:10.1144/ sp448.17Geol. Soc. Lond. Spec. Publications

Smit, J., Laffra, C., Meulenaars, K., and Montanari, A. (2012). Probable Late Messinian Tsunamiites Near Monte Dei Corvi, Italy, and the Nijar Basin, Spain: Expected Architecture of Offshore Tsunami Deposits. Nat. Hazards 63, 241-266. doi:10.1007/s11069-011-9947-9

Sørensen, B. E. (2013). A Revised Michel-Lévy Interference Colour Chart Based on First-Principles Calculations. ejm 25, 5-10. doi:10.1127/0935-1221/2013/00252252

Strahan, A., Gibson, W., Cantrill, T. C., Sherlock, R. L., and Dewey, H. (1920). Iron Ores (contd.) Pre-carboniferous and Carboniferous Bedded Ores of England and Wales, Vol. XIII. London): The Lords Commissioner of His Majesty's Treasury, 131.

Sturesson, U., Heikoop, J. M., and Risk, M. J. (2000). Modern and Palaeozoic Iron Ooids-A Similar Volcanic Origin. Sediment. Geology. 136, 137-146. doi:10.1016/S0037-0738(00)00091-9

Suess, E., Von Huene, R., et al. (1990). Proceedings of the Ocean Drilling Program, Scientific Results, 112, College Station: Ocean Drilling Program.

Talavera, C., Martínez Poyatos, D., and González Lodeiro, F. (2015). SHRIMP $\mathrm{U}-\mathrm{Pb}$ Geochronological Constraints on the Timing of the Intra-alcudian (Cadomian) Angular Unconformity in the Central Iberian Zone (Iberian Massif, Spain). Int. J. Earth Sci. (Geol Rundsch) 104, 1739-1757. doi:10.1007/s00531-015-1171-5

Taylor, K. G., and Konhauser, K. O. (2011). Iron in Earth Surface Systems: A Major Player in Chemical and Biological Processes. Elements 7, 83-88. doi:10.2113/ gselements.7.2.83 
Taylor, K. G., and Macquaker, J. H. S. (2000). Early Diagenetic Pyrite Morphology in a Mudstone-Dominated Succession: the Lower Jurassic Cleveland Ironstone Formation, Eastern England. Sediment. Geology. 131, 77-86. doi:10.1016/ S0037-0738(00)00002-6

Taylor, K. G., and Macquaker, J. H. S. (2011). Iron Minerals in Marine Sediments Record Chemical Environments. Elements 7, 113-118. doi:10.2113/ gselements.7.2.113

Terry, R. D., and Chilingar, G. V. (1955). Summary of "Concerning Some Additional Aids in Studying Sedimentary Formations," by M. S. Shvetsov. J. Sediment. Res. 25, 229-234. doi:10.1306/74d70466-2b21-11d7$8648000102 \mathrm{c} 1865 \mathrm{~d}$

Todd, S. E., Pufahl, P. K., Murphy, J. B., and Taylor, K. G. (2019). Sedimentology and Oceanography of Early Ordovician Ironstone, Bell Island, Newfoundland: Ferruginous Seawater and Upwelling in the Rheic Ocean. Sediment. Geology. 379, 1-15. doi:10.1016/j.sedgeo.2018.10.007

Torsvik, T. H., and Cocks, L. R. M. (2013). Chapter 2 New Global Palaeogeographical Reconstructions for the Early Palaeozoic and Their Generation. Geol. Soc. Lond. Mem. 38, 5-24. doi:10.1144/M38.2

Torsvik, T. H., and Cocks, L. R. M. (2017). "Climates Past and Present," in In Earth History and Palaeogeography. Editors T. H. Torsvik and L. R. M. Cocks (Cambridge: Cambridge University Press), 271-287.

Torsvik, T. H., and Rehnström, E. F. (2003). The Tornquist Sea and BalticaAvalonia Docking. Tectonophysics 362, 67-82. doi:10.1016/S0040-1951(02) 00631-5

Trabucho-Alexandre, J. (2015). "Organic Matter-Rich Shale Depositional Environments," in In Fundamentals of Gas Shale Reservoirs. Editor R. Rezaee (Hoboken: Wiley), 21-45. doi:10.1002/9781119039228.ch2

Trythall, R. J. B., Eccles, C., Molyneux, S. G., and Taylor, W. E. G. (1987). Age and Controls of Ironstone Deposition (Ordovician) North Wales. Geol. J. 22, 31-43. doi:10.1002/gj.3350220505

Van Houten, F. B., and Arthur, M. A. (1989). Temporal Patterns Among Phanerozoic Oolitic Ironstones and Oceanic Anoxia. Geol. Soc. Lond. Spec. Publications 46, 33-49. doi:10.1144/GSL.SP.1989.046.01.06

Van Houten, F. B., and Bhattacharyya, D. P. (1982). Phanerozoic Oolitic Ironstones--Geologic Record and Facies Model. Annu. Rev. Earth Planet. Sci. 10, 441-457. doi:10.1146/annurev.ea.10.050182.002301

Van Houten, F. B. (2000). "Ooidal Ironstones and Phosphorites-A Comparison from a Stratigrapher's View," in Marine Authigenesis from Global to Microbial SEPM Special Publication. Editors C. R. Glenn, L. Prévôt-Lucas, and J. Lucas (Oklahoma: Society for Sedimentary Geology)), 127-132. doi:10.2110/ pec.00.66.0127

van Staal, C. R., Barr, S. M., and Murphy, J. B. (2012). Provenance and Tectonic Evolution of Ganderia: Constraints on the Evolution of the Iapetus and Rheic Oceans. Geology 40, 987-990. doi:10.1130/g33302.1

van Staal, C. R., Dewey, J. F., Niocaill, C. M., and McKerrow, W. S. (1998). "The Cambrian-Silurian Tectonic Evolution of the Northern Appalachians and British Caledonides: History of a Complex, West and Southwest Pacific-type Segment of Iapetus," in In Lyell: The Past Is the Key to the Present. Editors D. J. Blundell and A. C. Scott (London: Geological Society Special PublicationThe Geological Society)), 143, 197-242. doi:10.1144/ gsl.sp.1998.143.01.17

Vandenbroucke, T. R. A., Emsbo, P., Munnecke, A., Nuns, N., Duponchel, L., Lepot, K., et al. (2015). Metal-induced Malformations in Early Palaeozoic Plankton Are Harbingers of Mass Extinction. Nat. Commun. 6, 7966, 2015. https://www.nature.com/artic les/ncomm s8966. doi:10.1038/ncomms8966

Veron, J. E. N. (2008). Mass Extinctions and Ocean Acidification: Biological Constraints on Geological Dilemmas. Coral Reefs 27, 459-472. doi:10.1007/ s00338-008-0381-8

Von Wagoner, J. C., Posamentier, H. W., Mitchum, R. M., Vail, P. R., Sarg, J. F., Loutit, T. S., et al. (1988). "An Overview of Sequence Stratigraphy and Key Definitions," in Sea Level Changes - an Integrated Approach, SEPM 42. Editors C.K. Wilgus, B.S. Hastings, C.G.S.C. Kendall, H.W. Posamentier, C.A. Ross, and J.C. Van Wagoner, 39-45.

Walker, L. J., Wilkinson, B. H., and Ivany, L. C. (2002). Continental Drift and Phanerozoic Carbonate Accumulation in Shallow-Shelf and Deep-Marine Settings. J. Geology. 110, 75-87. doi:10.1086/324318
Wang, C., Mitchell, R. N., Murphy, J. B., Peng, P., and Spencer, C. J. (2021). The Role of Megacontinents in the Supercontinent Cycle. Geology 49, 402-406. doi:10.1130/G47988.1

Watkins, R. T., Ridley, M. K., Pougnet, M. A. B., and Willis, J. P. (1995). Determination of Rare-Earth Elements in Coal Using Microwave Digestion and Gradient Ion Chromatography. Chem. Geology. 121, 273-283. doi:10.1016/ 0009-2541(94)00119-S

Webby, B. (2002). "Patterns of Ordovician Reef Development," in In Phanerozoic Reef Patterns SEPM Special Publication. Editors W. Kiessling, E. Flügel, and G. Golonka. doi:10.2110/pec.02.72.0129

Wefer, G., BergerRichter, C., et al. (2002). Proceedings of the Ocean Drilling Program, Scientific Results, 175, College Station: Ocean Drilling Program.

Wigley, R. A., and Compton, J. S. (2013). Microstratigraphy of a Miocene Layered Phosphatic Pebble from the Western Margin of South Africa. Sedimentology 60, 666-678. doi:10.1111/j.1365-3091.2012.01355.x

Wilde, P., Quinby-Hunt, M. S., and Berry, W. B. N. (1990). "Vertical Advection from Oxic or Anoxic Water from the Main Pycnocline as a Cause of Rapid Extinction or Rapid Radiations," in In Extinction Events in Earth History. Editors E.G. Kauffman and O.H. Walliser (Berlin, Heidelberg: SpringerVerlag), 85-98.

Won, M.-Z., and Below, R. (1999). Cambrian Radiolaria from the Georgina Basin, Queensland, Australia. Micropaleontology 45, 325-363. doi:10.2307/1486119

Woodcock, N. H. (1990). Sequence Stratigraphy of the Palaeozoic Welsh Basin. J. Geol. Soc. 147, 537-547. doi:10.1144/gsjgs.147.3.0537

Yang, G., Li, Y., Santosh, M., Yang, B., Yan, J., Zhang, B., et al. (2012). Geochronology and Geochemistry of Basaltic Rocks from the Sartuohai Ophiolitic Mélange, NW China: Implications for a Devonian Mantle Plume within the Junggar Ocean. J. Asian Earth Sci. 59, 141-155. doi:10.1016/ j.jseaes.2012.07.020

Yilmaz, İ. Ö., Göncüoğlu, M. C., Demiray, D. G., and Gedik, İ. (2015). An Approach to Paleoclimatic Conditions for Devonian (Upper Lochkovian and Middle Givetian) Ironstone Formation, NW Anatolian Carbonate Platform. Turkish J. Earth Sci. 24, 21-38. doi:10.3906/yer-1406-7

Young, T. P. (1989). "Eustatically Controlled Ooidal Ironstone Deposition: Facies Relationships of the Ordovician Open-Shelf Ironstones of Western Europe," in In Phanerozoic Ironstones Geological Society Special Publication No. 46. Editors T. P. Young and W. E. G. Taylor (London: Geological Society)), 46, 51-63. doi:10.1144/gsl.sp.1989.046.01.07Geol. Soc. Lond. Spec. Publications

Young, T. P., Gibbons, W., and McCarroll, D. (2002). Geology of the Country Around Pwllheli. England and WalesLondon: Memoir of the British Geological Survey. Sheet 134.,

Young, T. P. (1992). Ooidal Ironstones from Ordovician Gondwana: a Review. Palaeogeogr. Palaeoclimatol. Palaeoecol. 99, 321-347. doi:10.1016/00310182(92)90021-V

Young, T. P., Young, T. P., and Taylor, W. E. G. (1989). "Phanerozoic Ironstones: an Introduction and Review," in Phanerozoic Ironstones Geological Society Special Publications No 46 (London: Geological Society)), ix-xxv. doi:10.1144/ gsl.sp.1989.046.01.02

Conflict of Interest: The authors declare that the research was conducted in the absence of any commercial or financial relationships that could be construed as a potential conflict of interest.

Publisher's Note: All claims expressed in this article are solely those of the authors and do not necessarily represent those of their affiliated organizations, or those of the publisher, the editors and the reviewers. Any product that may be evaluated in this article, or claim that may be made by its manufacturer, is not guaranteed or endorsed by the publisher.

Copyright $\odot 2021$ Dunn, Pufahl, Murphy and Lokier. This is an open-access article distributed under the terms of the Creative Commons Attribution License (CC BY). The use, distribution or reproduction in other forums is permitted, provided the original author(s) and the copyright owner(s) are credited and that the original publication in this journal is cited, in accordance with accepted academic practice. No use, distribution or reproduction is permitted which does not comply with these terms. 